\title{
Izvori, geneza i priroda secesionističke retorike u Republici Srpskoj
}

\author{
ALEKSANDAR SAVANOVIĆ, ALEKSANDAR VRANJEŠ, \\ NEVENKO VRANJEŠ, ŽELJKO BUDIMIR
}

Fakultet političkih nauka, Univerzitet u Banjoj Luci

\begin{abstract}
Sažetak
Bosna i Hercegovina (BiH) je složena državna zajednica sastavljena od dva entiteta i tri konstitutivna naroda. Ta činjenica je posljedica građanskog rata 1992-95. godine, koji je promijenio etničku strukturu BiH. U institucionalnom smislu entitetima je u Dejtonu dat vrlo visok nivo političke samostalnosti. Tzv. "entitetski veto" je nastao u Dejtonu i primjenjuje se u mnogim ključnim tijelima - od Doma naroda, Predstavničkog doma Parlamentarne skupštine $\mathrm{BiH}$, do Predsjedništva $\mathrm{BiH}$. Pored toga, tvrdi se da $\mathrm{BiH}$ nema tzv. unutrašnje priznanje i mnogi od aktera na političkoj sceni zagovaraju radikalne ustavne promjene koje bi narušile ili čak potpuno promijenile "Dejtonsku" arhitekturu BiH. Imajući u vidu ove faktore, ne iznenađuje prisutnost secesionističke retorike u političkom prostoru $\mathrm{BiH}$. U ovom radu analiziraćemo secesionističku retoriku u Republici Srpskoj (RS) i pokušaćemo da opišemo moguću secesionističku strategiju u njenim glavnim linijama. Cilj nam je utvrditi da li se može reći da secesionistički argumenti, retorika i eventualno politike predstavljaju integralnu strategiju i koherentnu političku platformu ili su motivisane dnevnopolitičkim razlozima. Takođe ćemo pokušati utvrditi koliko je ova secesionistička retorika institucionalizovana, tj. koliko je zastupljena u zvaničnim dokumentima institucija RS i/ili glavnih političkih stranaka, a koliko ostaje na nivou društvenih pokreta i/ili pojedinačnih političkih subjekata.

Ključne riječi: Secesija, Republika Srpska, Bosna i Hercegovina, Ustav Bosne i Hercegovine, Dejtonski mirovni sporazum
\end{abstract}

\section{Uvod}

Secesionizam u Evropi nastavlja da postoji kao jedno od ključnih pitanja kako političke teorije tako i prakse. Čitav je niz regija, federalnih jedinica, teritorija koji, manje ili više otvoreno, propagiraju i žele vlastitu političku samostalnost: Baskija i 
Katalonija u Španiji, Veneto (Savanović, 2018) u Italiji, Škotska u Velikoj Britaniji, Korzika (Nossiter, 2017) u Francuskoj, Flandrija u Belgiji i Bavarska u Njemačkoj samo su neki od njih (Noack, 2017). Taj je secesionistički talas u suprotnosti (Beran, 1998: 44) s dominantnom idejom ujedinjenja Evrope, koja je obilježila institucionalne politike, ali i osjećanja Evropljana nakon pada Berlinskog zida. Upravo je slom komunističkog bloka inicirao "treći talas" secesionističkih pokreta u Evropi. ${ }^{1}$ U ovom talasu secesija se pojavila i tretirala kao legitimno uspostavljanje punog suvereniteta država koje su nakon 1945. prenijele dio svoje suverenosti na SSSR (Buchanan, 1991: 1-2; Lehning, 1998: ix). Pomenuti primjeri iz Španije, Italije, Velike Britanije, Francuske, Njemačke i Belgije, koje smo gore naveli, predstavljaju "četvrti talas" secesionizma u Evropi, koji je po svojoj prirodi suštinski različit u odnosu na "treći talas". Ova vrsta secesionizma zasniva se prije svega na ekonomskim i kulturnim argumentima i nema izraženu jaku ideološku notu.

Današnja BiH je država nastala u procesu raspada SFRJ, a nakon potpisivanja Dejtonskog mirovnog sporazuma (DMS) dobila je svoju sadašnju konstitutivnu formu. Bez obzira što je time završen građanski/disolucijski rat na tlu bivše Jugoslavije, do danas je ostala politički duboko podijeljena (Kasapović, 2005). Sastavljena od dva entiteta - Federacije BiH i Republike Srpske - i tri konstitutivna naroda Bošnjaka, Srba i Hrvata - BiH do danas nije ostvarila potpuno priznanje svih njenih konstituenata: Bošnjaci kao najbrojniji narod budućnost BiH vide kao državu bez entiteta i konstitutivnih naroda, ustrojenu na građanskom principu "jedan čovjek jedan glas" (ibid.: 18), što druga dva naroda - Srbi i Hrvati - vide kao politiku majorizacije. Srbi kao najbrojniji narod u entitetu Republika Srpska odbranu od moguće majorizacije vide u dosljednom pridržavanju izvornog teksta dejtonskog Ustava $\mathrm{BiH}$, ali onakvog kakav je napisan i potpisan 1995. godine, osporavajući oktroisane izmjene koje je politički sistem BiH pretrpio u prvoj deceniji nakon rata, a na štetu Republike Srpske, i samim tim dovodeći u pitanje legitimitet postojanja niza institucija nastalih kao proizvod nametnutih odluka visokih predstavnika. Dok Hrvati kao najmanje brojan konstitutivni narod $\mathrm{u} \mathrm{BiH}$, manje ili više otvoreno, zastupaju tezu o stvaranju trećeg hrvatskog entiteta u BiH. U suštini, politički predstavnici sva tri konstitutivna naroda konstantno tvrde da su oni narodi koje predstavljaju nezadovoljni postojećim stanjem i budućnost $\mathrm{BiH}$ vide u potrebi za ustavnim promjenama (Vuković, Savanović, Vranješ, 2016).

Kada se u domaćoj i međunarodnoj javnosti govori o secesionizmu u BiH, misli se prije svega na mogućnost da Republika Srpska pod određenim uslovima u nekoj doglednoj budućnosti raspiše referendum o nezavisnosti na vlastitoj teritoriji.

1 Prvi talas odnosi se na situaciju nakon Prvog svjetskog rata i potrebe da se legitimira status država nastalih raspadom Austro-Ugarske i Otomanskog carstva. Drugi talas odnosi se na proces dekolonizacije nakon Drugog svjetskog rata. 
Upotrebom pojma "secesionizam" u daljem tekstu autori ne zauzimaju stav u tom pogledu, nego će navedeni termin koristiti generički, uz napomenu da će isti podvrgnuti analizi u kontekstu istraživanja i do kraja rada ponuditi odgovor na markiranu dilemu. Namjera nam je da ispitamo: 1) razmjere (zastupljenost, aktere-nosioce, institucionalizaciju); 2) genezu; i 3) svrhu/cilj secesionističke retorike u RS.

Teza o mogućem secesionizmu Republike Srpske kao političkom procesu je teorijski zanimljiva jer ima elemente oba gore opisana secesionistička talasa: u određenim argumentacijama zagovornika secesije u javnom prostoru ona se jasno referiše na procese raspada SFRJ i u tom smislu pripada kontekstu "trećeg talasa", dok se istovremeno oslanja i na argumentacije tipične za savremene secesionističke pokrete "četvrtog talasa" u drugim dijelovima Evrope. Tako se, na primjer, kontekst "trećeg talasa" jasno može vidjeti u jednom od ključnih argumenata zagovornika ove teze - tvrdnji da je $\mathrm{BiH}$ nastala nelegitimnim preglasavanjem srpskog naroda i unilateralnom separacijom od Jugoslavije; dok se kontekst "četvrtog talasa" može vidjeti u potenciranju ekonomske i političke iracionalnosti i neodrživosti $\mathrm{BiH}$, posebno kada je riječ o hegemonističkim tendencijama najbrojnijeg, bošnjačkog, naroda i disfunkcionalnosti samog političkog sistema. U diskusiji koja slijedi ove ćemo argumente detaljno analizirati.

\section{Metodologija}

Za potrebe analize ovako postavljene teme proveli smo nekoliko standardnih istraživačkih postupaka koji se koriste u istraživanju sličnih tema. Prvo, uradili smo analizu sadržaja programskih dokumenata parlamentarnih političkih stranaka. Drugo, proveli smo analizu sadržaja odluka donesenih od strane relevantnih institucija: Vlade RS i Narodne skupštine RS. Treće, uradili smo analizu sadržaja dokumenata koji reprezentuju relevantne izvore za stav drugih aktera, a koji su bitni za razumijevanje teme, poput OHR. U radu je primjenjena kvalitativna analiza sadržaja gdje je kao jedinica analize uzeta misaona konstrukcija odnosno sadržaj koji se direktno odnosi ili je u neposrednoj vezi sa institutom secesije. Takođe, akcenat je stavljen na diskurzivnu analizu sadržaja i analizu vrijednosnih sudova i zapažanja ključnih aktera, učesnika političkog života kao i donosioca odluka.

Za registrovanje stavova javnosti koristili smo istraživanja koja su na tu temu provodili drugi istraživački subjekti, a mi smo komparativno obradili njihove rezultate. Ulazne podatke koje smo željeli dobiti možemo strukturisati na sljedeći način: 1. Frekvencija pojavljivanja teme secesije RS u programskim dokumentima političkih partija u RS i BiH. 2. Frekvencija pojavljivanja teme secesije RS u medijima. 3. Frekvencija pojavljivanja teme secesije RS u odlukama i dokumentima institucija RS (Vlada RS, Parlament RS). 4. Interpretacija i frekvencija teme secesije u dokumentima i izjavama OHR. 5. Stavovi građana RS o nezavisnosti. 
Ovako dobijene podatke koristili smo da: (i) predstavimo prisutnost teme secesije u političkom diskursu te da dešifrujemo dominantno političko stajalište i argumentacije koje se koriste u ovom kontekstu; (ii) da ispitamo koliko su stavovi javnosti kompatibilni s dominantnim političkim stajalištem; (iii) da ispitamo da li, u kojoj mjeri i koji politički subjekti prihvataju secesiju bilo kao politički pravac djelovanja ili kao temu koja treba biti zastupljena u javnosti, te svojim djelovanjem potpomažu formiranje dominantnog političkog stajališta; (iv) da li i u kojoj mjeri institucije RS prate u svojim oficijelnim odlukama dominantno političko stajalište po pitanju secesije.

\subsection{Teorijski okvir i pregled literature}

Kada se vratimo na pojam secesije u najširem smislu, naša namjera nije da ulazimo u striktno formalno-pravne aspekte ovog pitanja, već ćemo pokušati predstaviti i objasniti genezu (uzroke), razmjere i političku prirodu secesionističkog diskursa $\mathrm{u}$ RS. Na temu potencijalne secesije Republike Srpske u novije vrijeme se pojavila jedna nova studija (Ker-Lindsay, 2016) i ovaj tekst je u mnogome zamišljen i kao dopuna tog istraživanja.

Kao širi teorijski okvir koristićemo sistematizaciju argumenata pro-secesije kako su ih naveli A. Buchanan i mnogi drugi autori koji su razrađivali pojedine od ovih argumenata: Bartkus (1999), Lehning (1998), Beran (1998), Freeman (1998), Moltchanova (2009), Agnieli (2015), Wilkins (2000), Pavković i Radan (2007), Lefkowitz (2008) itd. Razlog za takav odabir leži u tome što je fokus u tim radovima na striktno političkoj teoriji secesije, a ne pravnoj, što je na tragu pristupa koji i mi ovdje želimo primjeniti na slučaju BiH. Politička teorija secesije sadrži "pozitivnu teoriju" (Buchanan, 1991: 2) koja odgovara na pitanja "ko", "kada", "pod kojim uslovima" može provesti secesiju, i "normativnu teoriju secesije" koja odgovara na pitanja tipa "na kojim osnovama i pod kojim uslovima je secesija moralno opravdana? ... koji metodi za dostizanje secesije su moralno opravdani?" (ibid.: 3) i sl. Vidjećemo da protagonisti secesionizma u Republici Srpskoj prave svojevrsnu kompilaciju ovih argumenata.

Radi se o sljedećim argumentima:

Argument "zaštita slobode", koji je gotovo trivijalan: ostati ili ne ostati u nekoj zajednici mora biti stvar slobodne odluke - prema tome, onaj ko brani slobodu mora zagovarati pravo na secesiju (ibid.: 29; Hoppe, 1998; Mises, 1985: 109; Pavković i Radan, 2007: 200). Argument je baziran na tzv. "harm principle": nedopustivo je miješanje u aktivnosti i poslove pojedinca sve dok njegovi izbori/akcije ne ugrožavaju drugog. Kada ovo primjenimo na secesiju, glasi: nedopustivo je ograničavati nečiju odluku da izađe ako ta odluka ne ugrožava druge. ${ }^{2}$

2 Problem s ovom argumentativnom strategijom je u definisanju utilitarne margine: ko može (ili može biti ovlašćen) da procjeni da su nečiji interesi ugroženi? Ovo naročito dolazi do izražaja u 
Argument "liberalni paradoks", koji se odnosi na tzv "paradoks tolerancije" u liberalnoj doktrini: paradoksalnu situaciju tolerisanja neliberalnih ili čak antiliberalnih filozofskih i/ili političkih sistema. Kako se liberalni sistemi mogu postaviti prema ovim sistemima? - Ako ih zabrane, onda su kontradiktorni sa samim sobom: jer ne dopuštaju bilo koje uvjerenje koje je neagresorsko prema drugome. S druge strane, ukoliko im se dopusti egzistiranje unutar liberalne države, onda jedna liberalna država unutar sebe ima jedan prostor koji to nije. Secesija može biti konceptualni odgovor na ovaj izazov: dopustiti ljudima koji žele da žive po neliberalnom svjetonazoru da to i urade, na način da se odvoje od liberalnog dijela društva (Buchanan, 1991: 34).

Argument "ograničenog cilja političkog udruživanja", čiji je smisao u sljedećoj matematici: ako A, B, C i D formiraju političku zajednicu Q s ciljem da ostvare politički cilj X, zašto nakon ostvarenja X [smisla i cilja Q] ne bi bio dozvoljen unilateralni izlazak za nekog od članova? Zašto bi se zahtjevalo da D ostane u zajednici Q i nakon što je X ostvaren (ibid.: 36)?

Argument "olakšavanja ulaska", koji propagira da secesija bude taksativno navedena kao pravo u ustavu, kao i adekvatne procedure njene primjene, jer to relaksira odnose i omogućava lakši ulazak u političku zajednicu, naročito u "eksperimentalnim zajednicama" - kakva je npr. EU (ibid.: 37; Chen i Ordeshook, 1994).

Argument "diskriminatorne redistribucije", koji je prost i jedan od najčešćih ${ }^{3} u$ secesionističkim pokretima "četvrtog talasa": tvrdi se da centralna vlast poreskom politikom vrši transfer kapitala iz jedne regije u drugu te na taj način stvara diskriminatornu redistribuciju (Buchanan, 1991: 40; Freeman, 1998: 20; Bartkus, 1999; Wellman, 2005).

Argument "povećanja efikasnosti" (Buchanan, 1991: 45; Bartkus, 1999), kojim se tvrdi da secesija može biti opravdana kada je država ekonomski neefikasna tvorevina, pa odvajanje daje prostora za uspostavu ekonomski efikasnije organizacije na odvojenoj teritoriji.

Argument "samoopredjeljenja ili nacionalistički argument" (Buchanan, 1991: 48; Freeman, 1998: 22; Costa, 2003; Wellman, 2005), klasičan argument o pravu na samoopredjeljenje, koji u čistoj formi glasi: "svaki narod ima pravo na svoju državu ... političke i kulturne (ili etničke) granice moraju se podudarati” (Buchanan, 1991: 48).

činjenici da secesija podrazumijeva i teritorijalni zahtjev. Npr. u problemu prirodnih bogatstava na secesionističkoj teritoriji, koji je analogan problemu odliva "ljudskog kapitala" u emigraciji (Buchanan, 1991: 30).

3 Tako baskijski secesionisti tvrde da je stopa koju Španija uzima od njih porezima više od tri puta veća nego što se to vrati u region kroz državnu potrošnju i investicije (Buchanan,1991: 41); a secesionisti iz Veneta tvrde da je regija Veneto "ugušena italijanskim fiskalnim pritiskom koji iznosi 60\%, ponekad i 70\%” (Savanović, 2018). 
Argument “očuvanja kultura” (ibid.: 64; Moltchanova, 2009), koji je kompatibilan s prethodnim i zasnovan na tvrdnji da u velikim multikulturnim državama kultura manjinske zajednice može biti ugrožena. Stoga secesija te zajednice može biti tretirana kao način da se to ugrožavanje onemogući.

Argument "rektifikacijske pravde" (Buchanan, 1991: 67), koji Buchanan koristi u smislu nedobrovoljne aneksije neke teritorije u nekom prošlom vremenu, što proizvodi "najjednostavniji i najintuitivniji argument za secesiju": jedna regija ima pravo na secesiju ako je bila nepravedno inkorporirana u veću jedinicu. U tom slučaju "secesija je prosto vraćanje ukradenog imanja legitimnom vlasniku" (ibid.).

Kontraktualistički argument "pristanka" i "analogija razvoda": politička zajednica mora biti rezultat slobodne volje, a ne nametanja. To je preformulacija ljudskog prava na "lično samoodređenje" u formu kolektivnog prava (Buchanan, 1991; Beran, 1998: 33, 37; Bishai, 1998: 93; Wellman, 2005; Lefkowitz, 2008; Moltchanova, 2009: 37-64), naročito u kontekstu prava nad teritorijom (Agnieli, 2015). Ovaj se argument često reinterpretira kao "libertarijanski kriterij” (Mises, 1985: 109) kojim se tvrdi da, ako jedna grupa želi da izađe, sama ta želja je dovoljna legitimacija za secesiju. Međutim, u pitanju su dva različita teorijska kriterija. Argument pristanka kaže da politička zajednica nastaje na osnovu saglasnosti, pa se stoga može i razdvojiti na legitiman način samo uz saglasnost strana. Zapravo, baš ovaj pokušaj teorijske varke koji protagonisti secesionizma u Republici Srpskoj pokušavaju govori jako puno o stvarnim namjerama i dometima secesionističke retorike.

Osnovno teorijsko stanovište autora ovog teksta po pitanju secesije je kontraktualističko: secesija može biti kredibilan akt isključivo u slučaju saglasnosti i/ili pristanka strana u aranžmanu (Savanović, 2019: 149-161). To je normativni kriterij koji proizilazi iz shvatanja ustava kao političkog ugovora. DMS je tipičan primjer takvog ustavnog aranžmana - kako formalno, naime u pitanju je međunarodni ugovor, tako i po suštini. Stoga sve prethodno navedene argumentacije i teorijska uporišta koja reprezentuju protagonisti secesionizma mogu biti samo ojačavajuće strategije za secesioniste, ali ne mogu pružiti dovoljan uslov za secesiju. Dakle, prema kriteriju "pristanak" eventualna secesija Republike Srpske moguća je jedino i samo ako dobije saglasnost "druge" strane u političkom ugovoru - ovdje to prije svega znači političkih predstavnika Bošnjaka. Međutim, upravo to je ona vrsta argumentacije koja u secesionističkoj retorici iz RS upadljivo nedostaje, premda su je akteri nesumnjivo svjesni, ili bi morali biti. Činjenica da je BiH konsocijacija (Kasapović, 2005) ne mijenja ovu ocjenu i ni na koji način ne može poslužiti kao osnova da se kriterij saglasnosti isključi. Naprotiv, konsocijacijska priroda DMS te činjenica da je BiH "podijeljeno" društvo samo ojačavaju zahtjev za saglasnosti. Ignorisanje ovog kriterija i/ili njegovo reinterpretiranje kao "libertarijanskog načela" predstavlja jedan od očitih argumenata u prilog glavnom zaključku ovog teksta. Vidjećemo 
da kriterij pristanka zapravo i postoji kao bazična strategija secesionista u RS, ali ako je čitan na jedan specifičan način koji ćemo ovdje predložiti.

Naravno, postoje i drugi argumenti koje različiti secesionistički pokreti koriste, kao i njihove teorijske interpretacije u zavisnosti od lokalnih specifičnosti. Takođe, različiti secesionistički pokreti akcente stavljaju na neke od ovih argumenata, potencirajući određene strategije, a druge koristeći kao podršku. Selekcija koju smo ovdje predložili odabrana je kao analitičko sredstvo da se razotkrije priroda secesionističkog diskursa u RS. To bi trebalo biti jasno kada provučemo argumentativne strategije secesionističkog diskursa u RS kroz ovaj teorijski ključ.

\section{Istraživanje}

Prije svega, potrebno je pokušati dešifrovati subjekte (nosioce) secesionističkog diskursa u RS. Analiza i provedeno istraživanje pokazuju sljedeće podatke i obrasce.

\subsection{Političke partije}

Kada se analiziraju program i političke platforme vodećih političkih stranaka u RS, jasno se vidi generalna opredjeljenost ka poštovanju postojećeg ustavnog poretka $\mathrm{BiH}$, te shodno tome i teritorijalnog integriteta. Direktne pozive na secesiju gotovo da nije moguće pronaći.

Kao izuzetak u javnosti se izdvaja vladajuća partija u RS Savez nezavisnih socijaldemokrata (SNSD) čiji predstavnici, manje ili više otvoreno, u medijima zagovaraju ideje kao što su samostalnost, nezavisnost, otcjepljenje, disolucija $\mathrm{BiH}$ i sl. To primjećuje i Ker-Lindsay koji tvrdi da je predsjednik SNSD Milorad Dodik glavni promoter ideje o samostalnosti RS (Ker-Lindsay, 2016: 3). Pri tome treba primjetiti da Dodikovo zagovaranje nezavisnosti RS traje u kontinuitetu od 2006. godine. U tom kontekstu se može tumačiti i najava novog Ustava Republike Srpske iz 2017. godine, kada je iznesena tvrdnja da novi ustav neće biti secesionistički, ali da će omogućavati secesiju kao opciju (Mitrović, 2018). Kako bi to izgledalo u praksi, nismo u mogućnosti da odgovorimo jer do danas javnost nije bila upoznata da li uopšte postoje aktivnosti na izradi nacrta novog ustava niti šta bi bio njegov sadržaj.

Ideja o samostalnosti Republike Srpske može se pronaći i u programskim ciljevima SNSD. Naime na 5. Saboru SNSD 25. aprila 2015. godine donesena je stranačka deklaracija pod naslovom: "Republika Srpska - slobodna i samostalna budućnost i odgovornost". Ovo je definitivno prvi stranački dokument u istoriji RS koji predviđa mogućnost secesije, čak u formi programske platforme SNSD na osnovu sljedećih odredbi (Deklaracija SNSD, 2015: 2, 4, 6, 7, 8): 
Smatramo da Narodna skupština Republike Srpske kao najviši organ strane-potpisnice svih aneksa Dejtonskog sporazuma, treba donijeti odluke o samostalnosti Republike Srpske kao načinu ostvarivanja njenog ustavnopravnog položaja u Dejtonskoj BiH. (...)

Ukoliko do kraja 2017. godine ne bude vidljivih procesa i mjerljivih rezultata uspostavljanja pozicija Republike Srpske u skladu sa Aneksom 4. Dejtonskog mirovnog sporazuma, Narodna Skupština Republike Srpske treba u toku 2018. godine raspisati referendum o samostalnom statusu Republike Srpske. Na osnovu rezultata referenduma, organi vlasti Republike Srpske shodno ulozi strane utvrđene Aneksom 4. Dejtonskog mirovnog sporazuma, Federaciji BiH će predložiti mirno razdruživanje i obostrano istovremeno priznanje (ibid.: 6, 8).

Ova Deklaracija je značajna jer se prvi put jedan politički subjekt jasno i nedvosmisleno opredijelio da samostalnost RS bude bazični politički cilj njegovog djelovanja. Ipak, važno je primijetiti sljedeće: U prvom citatu ističe se da parlament treba donijeti odluku o samostalnosti RS kao načinu ostvarivanja njenog ustavnopravnog položaja u Dejtonskoj BiH. Drugim riječima samostalnost se u kontekstu ovoga poima kao viši stepen autonomije u okviru ustavnog uređenja $\mathrm{BiH}$, a ne kao nezavisnost koja a priori podrazumijeva secesiju. Samim tim primjećujemo da postoji izvjesna dvosmislenost u korišćenju izraza "samostalnost" jer može konotirati $\mathrm{s}$ jedne strane više autonomije, ali i put ka nezavisnosti, u zavisnosti od tumačenja. Upravo iz tog razloga ova Deklaracija je ostala na neki način kontroverzna, jer je kritičari uzimaju kao corpus delicti secesionistčke politike, dok je s druge strane brane argumentom da samostalnost ne znači nezavisnost.

Drugi citat odnosi se na zamišljeni operativni nivo primjene Deklaracije gdje se opisuje uslovno da će, ukoliko se Republici Srpskoj ne vrate ustavne nadležnosti do kraja 2017. godine, u 2018. godini biti raspisan referendum o samostalnom statusu RS, što u ovom slučaju eksplicitno predviđa disoluciju BiH. Ono što je važno primjetiti jeste da su prošle i 2017. i 2018. godina i da odredbe ove Deklaracije nisu provedene, odnosno da se nijedna od najavljenih mogućnosti nije desila u političkoj praksi. Zanimljivo je i da funkcioneri SNSD u javnom prostoru više ne spominju Deklaraciju. Iz tog razloga skloniji smo zaključku da je sadržaj ove Deklaracije imao svoju propagandnu ulogu u određenom momentu, a nikako karakter političke platforme. Samim tim što je navedeni period u Deklaraciji istekao bez ikakvih posljedica po unutrašnje političke prilike, a uzevši u obzir i činjenicu da SNSD nije obnovio, unaprijedio, doradio ili prepravio postojeću Deklaraciju, može se zaključiti da je ovaj stranački dokument u vrijeme pisanja ovog rada stavljen ad acta. 


\subsection{NVO i društveni pokreti}

Nezavisnost Republike Srpske je kao tema prisutna i na nivou NVO i društvenih pokreta. Na primjer, organizacije "SNP izbor je naš"4 i "Yes Srpska"5 (osnovana 2014. godine u gradu Istočno Sarajevo) se otvoreno zalažu za nezavisnost. Pri tome koriste tipičnu ikonografiju i simboliku:
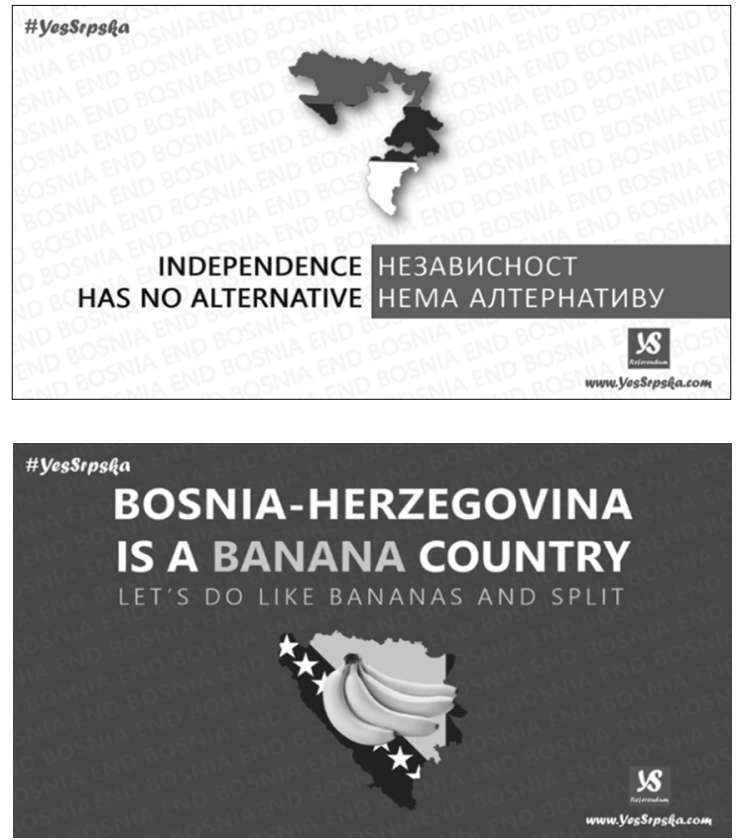

Zanimljivo je primjetiti da je fejsbuk stranica pokreta "Yes Srpska" u 2018. godini imala ukupno 13 objava, od čega se osam odnosilo na agitovanje u pravcu disolucije BiH i nezavisnosti RS. Posljednja objava bila je 13. novembra i zanimljivo je primjetiti da pokret nije obnovio svoju web-stranicu www.YesSrpska.com, iz čega se može izvesti zaključak da je u pitanju krajnje marginalna NVO bez velikog uticaja, uz dilemu da li je uopšte više i aktivna. Dakle, organizacije poput ovih nemaju širi uticaj na javnost niti je zabilježeno da imaju veći broj pristalica, te je teško njihove aktivnosti uzeti kao relevantne i reprezentativne.

${ }^{4} \mathrm{O}$ ovoj organizaciji i njenom agitovanju za secesiju i nezavisnost RS vidjeti više na: http:// www.plebiscitrs.org/.

5 https:/www.facebook.com/YesSrpska/. 


\subsection{Stav javnosti}

Prema dostupnim istraživanjima, javnost u Republici Srpskoj u većini podržava politike koje za cilj imaju samostalnost. Rezultati anketa su različiti, ali konstantno iznad $50 \%$ za nezavisnost.

Gallupovo istraživanje iz novembra 2010. pokazalo je da bi $87 \%$ podržalo referendum koji bio organizovan u svrhu nezavisnosti RS od BiH (Gallup Balkan Monitor, 2010).

Istraživanje koje je 2015. godine proveo Centar za društvena istraživanja $i$ analize iz Banja Luke pokazalo je značajno manju podršku politikama samostalnosti. Na pitanje "Da li samostalnost Republike Srpske treba da bude politički cilj za budućnost?" 53,5\% ispitanika zaokružilo je odgovor "da", njih 15,3\% odgovor "ne", dok je 31,1\% ispitanika reklo da nema stav o ovom pitanju. Slični su rezultati i kod pitanja "Podržavate li deklaraciju SNSD-a o slobodnoj i samostalnoj Srpskoj?", gdje je 54\% ispitanika zaokružilo odgovor "da", njih 14,8\% odgovor "ne", dok $31,2 \%$ ispitanika nema stav o ovom pitanju (Nezavisne novine, 2015). Mišljenja smo da su postavljena pitanja $u$ anketi prilično nerazumljiva prosječnom ispitaniku. Pitanju "Podržavate li deklaraciju SNSD-a o slobodnoj i samostalnoj Srpskoj?" moralo je da prethodi pitanje da li su ispitanici prvo pročitali navedenu Deklaraciju, pa tek onda tražiti mišljenje o istoj. Kako to nije bio slučaj, nije jasno da li su ispitanici uopšte bili upoznati sa tekstom Deklaracije, što predstavlja značajnu devijaciju.

Rezultati ispitivanja javnog mnijenja za ured stalnog koordinatora UN pokazali su da 55,2\% stanovnika RS podržava nezavisnost (Prism Research, 2015: 65), a iste podatke koristi i USAID kao podršku svom zaključku o postojanju jasnog separatističkog raspoloženja u RS (USAID, 2017: 25-27). I u najnovijem izvještaju ostaje se kod prethodnog zaključka: "stanovnici RS radije bi vidjeli da je $\mathrm{BiH}$ podijeljena na tri nezavisne države, ili da trenutni aranžman ostave nepromijenjen" (USAID, 2018: 31-32).

\subsection{Institucije Republike Srpske}

Ono što je u pitanju secesionizma RS od posebnog značaja je eventualno postojanje zvaničnih akata, odluka ili zakona institucija RS koji bi referisali na temu secesije. Premda se mnoge od odluka, zakona i aktivnosti tretiraju kao posredna priprema ${ }^{6}$ i pravljenje temelja za budući secesionizam, u zvaničnim odlukama institucija ova tema se vrlo rijetko pojavljuje. Moguće je pronaći tek nekoliko izuzetaka. Na primjer, Narodna skupština Republike Srpske je 22. februara 2008. donijela "Rezoluciju o nepriznavanju jednostrano proglašene nezavisnosti Kosova i Metohije i opredjeljenjima Republike Srpske" u kojoj se između ostalog kaže sljedeće:

${ }^{6}$ Takav je slučaj npr. s donošenjem Zakona o referendumu i građanskoj inicijativi. 
Ukoliko veći broj zemalja članica Ujedinjenih nacija, a prije svega Evropske Unije, prizna ovako proglašenu nezavisnost Kosova i Metohije, Narodna skupština smatra da bi time bio uspostavljen nov međunarodni princip i praksa u priznavanju prioritetnog prava na samoopredjeljenje, do razdruživanja. U tom slučaju, Narodna skupština Republike Srpske smatra da ima pravo da stav o svom državnopravnom statusu utvrdi putem neposrednog izjašnjavanja građana na referendumu. (...)

Ako se u institucijama Bosne i Hercegovine ne prihvate dejtonski položaj i ovlašćenja Republike Srpske, te se nastavi pritisak na Republiku Srpsku da se mijenja njen status protivno njenoj volji, ukoliko Bosna i Hercegovina uđe u proces međunarodnog priznavanja Kosova i Metohije, Republika Srpska će ući u proceduru utvrđivanja svog državnopravnog statusa, na osnovama demokratskog i mirnog rješavanja pitanja i odnosa u Bosni i Hercegovini (Narodna skupština Republike Srpske, 2008).

Premda Rezolucija nije dokument koji ima pravnu snagu i obaveznost, ovo su ipak jasne političke proklamacije ciljeva i opis uslova pod kojima se secesionizam može dogoditi. Rezolucija koristi temu secesije u defanzivnom i striktno profilaktičkom smislu očuvanja "dejtonskog poretka". Prvi dio Deklaracije takođe ima izričito profilaktičku svrhu sprječavanja "dalje uzurpacije nadležnosti RS", ali drugi dio može biti shvaćen kao platforma za proaktivno djelovanje. Unatoč tome jasno je da je frekvencija pojavljivanja secesionističke retorike u aktima NSRS gotovo nula te da je ograničena na neobavezujuće dokumente deklarativnog tipa, tj. da ostaje u domenu striktno političkih stavova, a ne proizvođenja pravne obligacije, te ima profilaktički karakter.

Važan izvor i svjedočanstvo za markiranje oficijelnog stava RS prema secesionizmu predstavljaju “izvještaji RS Savjetu Bezbjednosti UN", koje potpisuje Predsjednik RS (u mandatima 2010-2018. to je Milorad Dodik). U tim izvještajima se eksplicitno odbacuju secesionističke pretenzije RS. Konstanta u ovim izvještajima je stav: RS je posvećena dosljednom poštovanju DMS i suverenitetu BiH kako je predviđeno DMS. Karakterističan stav je:

Uprkos ovim izazovima, Vlada Republike Srpske ostaje u potpunosti opredijeljena za Dejtonski sporazum. Vlada poštuje pravnu strukturu, prava i obaveze iz ovog sporazuma - uključujući i one iz Ustava $\mathrm{BiH}$ - i insistira na tome da ih poštuju i druge potpisnice Dejtonskog sporazuma. To podrazumijeva poštovanje autonomije Republike Srpske i prava konstitutivnih naroda, garantovanih Ustavom $\mathrm{BiH}$, kao i neuplitanje u unutrašnja pitanja BiH. Suprotno navodima nekih kritičara Republike Srpske, Republika Srpska nema plan secesije od BiH. Kritičari Republike Srpske često pogrešno predstavljaju izjave zvaničnika Republike Srpske kojima osuđuju nezakonite promjene i pokušaje promjene dejtonske strukture, kao i nefunkcionalnu BiH kao rezultat takvih promjena. Vlada Republike Srpske 
nastavlja da podržava $\mathrm{BiH}$ u skladu sa ustavnim uređenjem, i nastaviće da se zalaže, političkim i pravnim sredstvima, za puno sprovođenje Dejtonskog sporazuma (XIX izvještaj RS, 2018: 4).

Ovakvi i slični stavovi ponavljaju se i u ostalim izvještajima u kojima se referiše na temu secesije (XVIII izvještaj RS, 2017: 3; XVI, 2016: 6; XV, 2016: 2; XI, 2014: 28).

U izvještaju XVII se navodi primjer s osporavanjem Dana Republike pred Ustavnim sudom $\mathrm{BiH}$ od strane Bakira Izetbegovića, kao primjer provokacije koja za cilj ima da plasira sliku o navodnom secesionizmu RS (XVII izvještaj RS, 2017: 8). Kada je Narodna skupština RS reagovala raspisivanjem referenduma o Danu Republike, to je iskorišteno od strane predstavnika Stranke demokratske akcije (SDA) kao argument da je u pitanju proba i priprema za referendum o otcjepljenju (ibid.: 9). Eksplicitno se navodi da je "kampanja o secesiji RS" lažna i isfabrikovana od strane SDA (ibid.: 2) i da to nije stvarna agenda RS: "Republika Srpska ne traži otcjepljenje od BiH. Republika Srpska, u stvari, radi na realizaciji decentralizovanog sistema koji je garantovan dejtonskim ustavom" (ibid.: 2). "SDA i njeni saveznici u međunarodnoj zajednici često pokušavaju da zadobiju podršku protiv Republike Srpske tvrdnjama da Republika Srpska planira da se otcijepi od BiH. Ova tvrdnja je netačna; Republika Srpska je u više navrata jasno istakla svoju opredijeljenost za Dejtonski sporazum i teritorijalni integritet BiH" (ibid.: 13).

U svim ovim izvještajima eksplicitno se odbacuju optužbe za secesionizam, a brojni primjeri koji se navode kao implicitno ili eksplicitno secesionistički, poput referenduma i krize oko Suda i tužilaštva BiH (XV izvještaj RS, 2016: 2), Dana Republike (XVIII izvještaj RS, 2017: 3, 19-25) i sl. se brane upravo suprotnim stavom: kao sredstvo očuvanja DMS i "dejtonske BiH" od antidejtonskih napada, a ne kao secesionistička platforma.

I pored ovih činjenica u više navrata je skrenuta pažnja da neke neformalne poruke jasno ukazuju na smjer koji dominira u institucijama, a on je jasno u pravcu "izgradnje državnosti RS". Tako se, na primjer, zastave i obilježja koje RS koristi tretiraju kao eksplicitna promocija političke nezavisnosti (OHR Report 40, 2011: 5). Zastava BiH postoji samo tamo gdje je to zakonska obaveza. Na ulazu u RS su table koje to naznačavaju s ćiriličnim pismom, a mnoštvo drugih simbola ukazuje na samosvojnost RS (Parish, 2013: 2). I mnogobrojni drugi mikroprimjeri pokazuju ovaj pravac. Jedan od glavnih argumenta u apelaciji o Danu Republike koju je Bakir Izetbegović podnio Ustavnom sudu BiH se odnosio na simboliku koja je otvoreno secesionistička (Savanović, 2017). 


\subsection{Percepcija međunarodne zajednice}

Ako sličnu metodologiju primjenimo na međunarodni plan, onda možemo vidjeti da medijska slika, dobijena na osnovu ad hoc analize, jeste takva da je tema secesije RS izrazito prisutna (Ashdown i Holbrooke, 2008). Dominantan stav može biti sažet na sljedeći način:

Mnogi političari, diplomate i analitičari vjeruju da bi proglašenje nezavisnosti Republike Srpske pokrenulo novi konflikt u BiH i više nasilja širom Balkana gdje bi etničke grupe pokušale da prekroje nacionalne granice. Međunarodni zvaničnici ponovljeno upozoravaju lidere Republike Srpske protiv secesije, dajući jasan stav da bi bila odbačena kao ilegalan akt i ne bi bila priznata od strane zapadnih sila (Savic i Filipovic, 2017).

Pri tome se secesionizam RS povremeno tretira kao instrument ruskog uticaja na Balkanu, preko Srba (New York Times, 2018). U smislu institucionalnih stavova o secesionizmu RS najznačajniji izvor su "izvještaji Visokog predstavnika za implementaciju mirovnog sporazuma u BiH Generalnom sekretaru Ujedinjenih nacija” (eng. OHR Reports). Analiza sadržaja Izvještaja koje je OHR redovno dostavljao u periodu 1996-2018. pokazuju da je tema secesionizma RS konstanta u ovim izvještajima od 2006. Karakterističan opis je sljedeći:

U izvještajnom je razdoblju došlo do pojačane i provokativne retorike iz RS, osporavanja i propitivanja postojanja države Bosne i Hercegovine, zalaganja za raspuštanje države i osporavanja funkcionalnosti države i njenih odgovornosti prema Ustavu BiH. Predsjednik RS Milorad Dodik najčešći je - iako sigurno ne i jedini zagovornik raspada države. Među mnogim problematičnim izjavama, na primjer, nedavno je rekao da je "BiH trula država koja ne zaslužuje postojati. BiH stalno potvrđuje svoju nesposobnost da postoji ... BiH se definitivno raspada i raspast će se prije ili kasnije. Što se mene tiče, nadam se da će se raspasti što je prije moguće.” Retorička kampanja za otcjepljenje uključivala je opetovano zagovaranje prava RS na samoopredjeljenje i česte izjave koje predviđaju raspad $\mathrm{BiH}$ i nezavisnost RS. Viši zvaničnici RS javno su priznali namjerno opstruisanje dejtonskih institucija, tražili da RS ima svoj put prema EU i uvjeravali da je na RS da odluči da li će Bosna i Hercegovina postojati ili ne. Takođe me zabrinjavaju stalne tvrdnje - suprotno Ustavu BiH - da su entiteti u stvari države (OHR Report 42, 2012: 5).

Ovakvi i slični stavovi konstantno su prisutni u izvještajima od 2006. godine (OHR Report 30, 2006: 21, 33; 31, 2007: 11, 29; 32, 2007: 59; 33, 2008: 5; 34, 2008: 5, 12-13; 35, 2009: 5; 36, 2009: 1, 8; 37, 2010: 19; 38, 2010: 1, 3-4; 39, 2011: 1, 15; 40, 2011: 1, 5; 41, 2012: 4; 42, 2012: 1, 5; 43, 2013: 1, 3-4; 44, 2013: 4; 45, 2014: 1, 4; 46, 2014: 1, 5; 47, 2015: 1; 48, 2015: 1, 4; 49, 2016: 1, 5; 50, 2016: 1, 5; 52, 2017: 1; 53, 2018: 2,6). 
Generalni zaključak koji se može izvesti iz analize ovih Izvještaja je sljedeći:

(1) RS konstantno prijeti ugrožavanjem suvereniteta $\mathrm{BiH}$ i konstantno ispoljava otvorene secesionističke pretenzije.

(2) Nosilac tih aktivnosti je M. Dodik i SNSD, premda se povremeno imenuju i drugi nosioci funkcija iz redova SNSD koji zagovaraju politiku secesije RS i/ili disolucije BiH. ${ }^{7}$

(3) Ovdje je važno uočiti da OHR izvještaji ne prave jasnu i snažnu razliku između "predstavnika RS" i "članova vladajuće partije" (OHR Report 33, 2008: 5). Tako se, na primjer, uz ime Dodika uobičajeno navodi "Predsjednik RS" ili "Premijer", a ne "predsjednik SNSD". Primjena takvog obrasca može voditi ka tome da činjenica da je SNSD istovremeno i vladajuća stranka u RS, a njeni članovi nosioci ključnih funkcija (predsjednik RS, premijer) zamagli stvari i secesionizam predstavi kao oficijelnu politiku RS, a ne političku platformu jedne od političkih partija. ${ }^{8}$

(4) Narodna skupština RS se u tom kontekstu takođe spominje (OHR Report 44, 2013: 4), naročito u kontekstu referenduma o Sudu i tužilaštvu BiH, u odlukama Visokog predstavnika (OHR Report 36, 2010: 8), ali i u kontekstu tehničkih stvari, kakva je na primjer markiranje međuentitetske linije razgraničenja. U upotrebi termina "granica" od strane NSRS, OHR vidi eksplicitnu secesionističku aktivnost (OHR Report 39, 2011: 15).

(5) Povremeno se pokušava uspostaviti veza s drugim secesionističkim žarištima, poput ukrajinske krize (OHR Report 45, 2014: 4) ili Kosova (OHR Report 44, 2013: 4; 40, 2011: 5; 38, 2010: 1, 3-4; 35, 2009: 5; 32, 2007: 59), a takođe se i reakcije RS zvaničnika na nezavisnost Crne Gore interpretiraju u tom kontekstu (OHR Report 31, 2007: 11; 30, 2006: 21, 33).

Za razumijevanje secesionizma u BiH važno je uočiti faktor vremena $\mathrm{i}$ istorijskog momenta u kome se pojavljuje, pa ovi izvještaji predstavljaju odličan izvor za to. Premda je secesionizam van svake sumnje prisutan kao ideja u RS od njenog nastanka, tema secesije se ne pojavljuje u ranijim izvještajima OHR do 2006. Ni sama riječ (termin) "secesija" (ili “nezavisnost") se ne susreće e u OHR izvještajima 1-29 u kontekstu otvorene i jasne politike RS, premda se neke formulacije mogu implicitno razumijevati na taj način. Upravo suprotno, jedna opaska (OHR Report 23, 2002: 56) konstatuje sveopštu saglasnost o nepovredivosti $\mathrm{BiH}$ granica u kontekstu kriza oko pokreta za nezavisnost Crne Gore i Kosova. Tamo gdje se tema ugroženosti su-

7 Npr. Nikola Špirić i/ili Nebojša Radmanović (OHR Report 42, 2012: 5; 50, 2016: 5).

8 Tako se u jednom izvještaju (OHR Report 31, 2007: 11) kaže da je ta vrsta politike "posuđena od SDS", što znači da ima transpartijski kontinuitet.

9 Važan izuzetak u tom smislu je OHR Report 5 (1997: 153-154), koji svjedoči da je secesionizam kao ideja bio prisutan već neposredno nakon DMS. 
vereniteta i teritorijalnog integriteta uopšte pojavljuje (i to kao hipotetička mogućnost), odnosi se prije svega na prijetnju izvana, a ne na unutrašnju secesiju jednog dijela države (OHR Report 22, 2002: 7; 19, 2001: 2, 7).${ }^{10}$ Prvi put se tema secesije kao program RS prema nezavisnosti pominje u Izvještaju OHR br. 30 (jun 2006), nakon čega je to konstanta u svim OHR izvještajima. Do tada se govorilo o "antidejtonskim" akcijama, ali bez specifikacije o secesionizmu, već se primarno radilo o osporavanju autoriteta OHR, blokadama reformskih procesa, ignorisanju i/ili osporavanju institucija države $\mathrm{BiH}$. Potpuno su dominirale druge teme. To je, naravno, posljedica i objektivnih okolnosti, jer je zemlja u tom periodu bila fokusirana na probleme postratne konsolidacije i oporavka: konsolidacije državnih institucija, ljudska prava, povratak izbjeglica, saradnje s ICTY, sukcesija, Brčko arbitraža, privatizacija, ekonomske reforme, reforme odbrane, nezavisnost medija, telekomunikacija itd.

Takođe je važno uočiti da secesionistička retorika koincidira s dolaskom Dodika i SNSD na vlast u RS, i datira iz perioda kampanje za opšte izbore 2006. Naročito je polemika Dodik ${ }^{11}$-Silajdžić uticala na fokusiranje političkih predstavnika SNSD i RS na temu secesije. Očito je da secesionizam predstavlja u nekoj mjeri refleks na Silajdžićevu politiku: "100\% Bosne”. Imajući u vidu rezultat izbora te promjenu kursa prema RS i praksama "prenosa nadležnosti”, pokazao se kao multiefikasan instrument i opravdao svoju upotrebu - kako u dnevnopolitičke svrhe dobijanja podrške glasača u RS tako i kao protektivna i profilaktička mjera prema agresivnim nastupima za "unitarizacijom" države i/ili izmjenom DMS. Ovo je, sa stanovišta zaključaka ovog rada, važno uočiti jer na bitan način doprinosi razumijevanju geneze, svrhe i dometa secesionističke retorike u RS.

Stav UN i EU po pitanju secesije RS slijedi obrazac iz OHR izvještaja i eksplicitno je negativan, i to ne samo u smislu političkog konteksta već i prava: "pod Dejtonskim sporazumom, RS nema pravo na secesiju" (European Parliament Resolution, 2016, Art. 7; Security Council Report, 2017). Vijeće za implementaciju mira (PIC) takođe prati ovaj obrazac (Communiqué of the Steering Board of the Peace Implementation Council, 2015). SAD su zauzele identičan kurs. Razlika je da postoji i institucionalna reakcija. Sankcije SAD prema Miloradu Dodiku motivisane su njegovim "antidejtonskim" ponašanjem, i konkretno secesionizmom (Reuters, 2017). I mnogi NVO izvještaji (BTI, 2003: 4; 2006: 3, 22; 2008: 5, 25-26; 2010:

${ }^{10}$ Na primjer: nezavisnost RS je konstatovana kao politička opcija u OHR Report 28 (2005: 6, 82), ali ne kao interna politika neke od strana u BiH i RS, već kao eksterna (uvežena) opcija iz Srbije: radi se o komentaru izjave Vuka Draškovića, tadašnjeg ministra spoljnih poslova Srbije i Crne Gore, u kontekstu nezavisnosti Crne Gore.

11 Naročito indikativno je da su dotadašnji izvještaji OHR označili Dodika i SLOGA koaliciju upravo u suprotnom kontekstu. Čak i u tako nacionalno napetoj situaciji kakva je bila u RS tokom NATO intervencije protiv SRJ, RS Vlada s premijerom Dodikom na čelu “ostaju posvećeni implementaciji Dejtona”(OHR Report 14, 1999: 22). 
28-29; 2012: 2, 4-6, 24, 29; 2014: 2, 45; 2016: 2, 5, 33; 2018: 5-7, 34), naučni (Kartsonaki, 2016) i stručni (Seham, 2015: 21) radovi ukazuju na istu interpretaciju secesionizma u RS kao realno postojeće prijetnje za stabilnost BiH.

Rekapitulirajući ove stavove, može se reći da je i medijska slika i oficijelni stav najvažnijih međunarodnih aktera da je (i) secesionizam konstantno prisutan u RS; (ii) da je njegov glavni nosilac Milorad Dodik; (iii) da je secesionistička retorika u RS jedan od glavnih rizika za stabilnost i budućnost BiH; (iv) da je secesionizam RS nelegalan. U suštini, secesionizam RS se uzima kao postojeći, ali bez ozbiljnije mogućnosti za legalno validnu realizaciju. Neka vrsta "prazne" prijetnje (Ker-Lindsay, 2016), koja i kao takva ipak ima negativne efekte (Kartsonaki, 2016; Parish, 2013) podjele i destabilizacije $\mathrm{BiH}$, te konsekventno tome i negativne ekonomske, bezbjednosne i druge efekte.

\section{Analiza}

Pokušaćemo sada navesti osnovne argumentativne strategije koje se koriste kao podrška zahtjevu za nezavisnošću RS, a koje smo uspjeli markirati iz analize medijskih sadržaja i programskih dokumenata koji referišu na tu temu.

\subsection{Argument nelegitimnosti}

Ova se argumentativna strategija pojavljuje na tri nivoa. Prvo, kao tvrdnja da je država $\mathrm{BiH}$ kao takva nastala nelegitimnim preglasavanjem na referendumu o nezavisnosti 1992., tj. da je u pitanju jednostrana secesija. Takva nezavisnost nije imala podršku Srba, o čemu je jasan dokaz Plebiscit srpskog naroda u BiH održan 9-10. novembra 1991. "Srbi nikada nisu prihvatili BiH kao državu i zato RS treba da se osamostali" (Dodik, 2014).

Drugo, tvrdi se da je postojeća BiH oktroisana. Ustav BiH nije pravi ustav koji je rezultat ustavotvorne skupštine i saglasnosti njenih građana, već je to 'Dejtonski' ustav, oktroisan i prihvaćen pod prinudom. "Ustav je stupio na snagu potpisivanjem, a ne ratifikacijom Aneksa 4" (Oellers-Frahm, 2005: 195). "Osnov ustavnopravne konstrukcije $\mathrm{BiH}$ je međunarodni ugovor i međunarodno pravo. To ukazuje na specifičnost nastanka $\mathrm{BiH}$ - više voljom međunarodne zajednice, nego njenih naroda" (SNSD, 2013: 10).

Treće, tvrdi se da je čak i takva $\mathrm{BiH}$ i njena ustavna arhitektura mijenjana ilegalnim pritiscima, prije svega Visokog predstavnika, i uglavnom na štetu RS, te da sve promjene ustavnopravnog poretka koje su nastale pod pritiskom nemaju legitimitet ni legalitet. S obzirom na masovan obim tih intervencija, postojeća država nema legitimitet u cjelini.

Rezultat ovih činjenica je da je BiH "vještačka tvorevina" koju niko ne želi u ovoj formi (ibid.: 77). 


\subsection{Argument diskriminacije}

Ova strategija se sastoji u tvrdnji: "BiH je 'loše mjesto' za Srpsku” (Dodik, 2014). Tvrdi se da RS nema nikakve koristi od Bosne i Hercegovine, već naprotiv, samo direktne ili indirektne štete. U tom smislu BiH predstavlja samo ekonomsko i fiskalno opterećenje za RS i u suštini otvorenu ili prikrivenu eksploataciju. Tako se često navodi podatak da RS plaća 22000 službenika u zajedničkim institucijama na nivou $\mathrm{BiH}$, a od njih nema nikakve koristi, što znači da RS finansira te ljude. Navodi se $\mathrm{i}$ argument da konstantna ocjena $\mathrm{BiH}$ kao nestabilne i rizične države nanosi značajnu štetu ekonomiji RS, te da bi bez tog lošeg imidža RS imala brži i snažniji razvoj (Deklaracija SNSD, 2015). Suština ovih argumenata je da RS trpi štetu zbog postojanja $\mathrm{BiH}$ te da je to neka vrsta diskriminacije i eksploatacije.

\subsection{Argument neefikasnosti}

Tvrdi se da je BiH "neuspješna država" (Dodik, 2017) koja nije u stanju da profunkcioniše na efikasan način. U tom smislu strategija se sastoji u tome da se dokaže kako je BiH politički i ekonomski iracionalan eksperiment. To nije ocjena samo zagovornika secesije, već je često prisutna dijagnoza i eksternih subjekata, koji vrlo često opisuju politički sistem BiH kao jedan od "najkomplikovanijih i najskupljih na svijetu" (Wybranowski, 2012), ali koji nije dao ni približno očekivane rezultate (Ker-Lindsay, 2016: 2). Međutim, to je, sa stanovišta secesionističkih politika RS, osobina isključivo Federacije $\mathrm{BiH}$ i države $\mathrm{BiH}$ zbog njihovih brojnih kantonalnih vlada i stotina ministara, te državne administracije i birokratije koja prelazi 23000 ljudi (SNSD, 2013: 43-44). Nasuprot tome, RS se posmatra kao vrlo efikasna politička organizacija s relativno visokom centralizacijom i lakom upravljivošću. Za zagovornike secesionizma vrlo je važno razumjeti zašto je BiH neuspješna država - osnovni uzrok je promjena sofisticirane "Dejtonske" arhitekture u pravcu "unitarizacije". Dejtonska BiH je sastavljena od tri konstitutivna naroda koji, zbog svog istorijskog iskustva, imaju različite i često dijametralno suprotne stavove o mnogim pitanjima. Zato je DMS predvidio da se samo mali broj odluka donosi na nivou $\mathrm{BiH}$. Postdejtonske intervencije u pravcu unitarizacije su dramatično povećale oblasti koje treba regulisati na nivou $\mathrm{BiH}$ i time otvorile prostor za neslaganja i nerješive sukobe te stoga blokade (XIV izvještaj RS, 2015: 5-7).

\section{4. "Nemoguća država"}

Prethodno opisane strategije "nelegitimnosti", "nepravednosti" i "iracionalnosti" spajaju se u sveobuhvatan politički koncept o BiH kao "nemogućoj državi” koju niko ne želi u ovakvoj formi, koja je nepravedna, neefikasna i stoga se neminovno mora raspasti. Premda je DMS dosljedno primjenio konsocijacijski model demokratije kao metod za relaksiranje političkih odnosa u tzv. "podijeljenim društvima", 
model nije profunkcionisao u $\mathrm{BiH}$ jer nedostaju "osnovni predpolitički preduslovi" za njega (Mackenzie, 2017). ${ }^{12}$ Tvrdnja je da je BiH "vještačka tvorevina" koja se održava samo zahvaljujući eksternom uticaju oličenom u OHR. U tom smislu BiH je "zadata država" (SNSD, 2013: 52). Čim taj eksterni uticaj nestane ili dovoljno oslabi, BiH će se raspasti na svoje sastavne dijelove.

\subsection{Argument "slaba država" "federalno-konfederalnog tipa"}

Ovaj argument je jedna vrsta kompleksne interpretacije ustavne istorije $\mathrm{BiH}$ koji ima za cilj da dokaže kako je BiH politička zajednica sastavljena od suverenih entiteta koji su prenijeli dio svojih ovlaštenja na centralnu državu, ali joj time nisu dali suverenost "prema unutra" (koja je ostala u entitetima), već samo prema spolja. Tvrdi se sljedeće. Ustav BiH je kreiran po modelu američkog ustava (ibid.: 8), a SAD su "zajednica suverenih država" (ibid.: 9). Navode se mnogobrojni komparativni primjeri koji to dokazuju: na primjer analogija između 10. amandmana na Ustav SAD i člana 3.3. Ustava BiH, kojima se jasno kaže da sve ingerencije koje nisu ustavom dodijeljene državi pripadaju članicama (ibid.: 10). Dodatni argument za tvrdnju da je BiH “državna zajednica” je činjenica da su anekse DMS potpisali i entiteti (ibid.: 11), na koju su ukazivali i mnogi nezavisni istraživači (Oellers-Frahm, 2005: 194), a što se interpretira kao dokaz da su "entiteti unijeli svoju državnost u BiH" (OHR Report 40, 2011: 1; 34, 2008: 12-13), koja je samim time "zajednica", "unija" entiteta koji su imali "međunarodno-pravni subjektivitet" (XIV izvještaj RS, 2015: 5; SNSD, 2013: 11, 14, 56 i d.). ${ }^{13}$ Tvrdi se da BiH nije bila strana u DMS, već da je tek nastala u DMS (SNSD, 2013: 17). Takođe se u kontekstu ove strategije naglašava da čitav niz termina i rješenja iz Ustava BiH sugeriše da je $u$ pitanju zajednica suverenih entiteta (ibid.: $25 \mathrm{i}$ dr.). Poenta je da je $\mathrm{BiH}$ nastala prenošenjem ovlasti entiteta na državu (ibid.: 12, 19-22) te da stoga suverenost počiva u entitetima, a ne na državi $\mathrm{BiH}$, te da je $\mathrm{BiH}$ suverena "država samo prema spolja" (ibid.: 27, 33). Otuda i definicija: $\mathrm{BiH}$ je državna zajednica "konfederalno-federalnog tipa" (ibid.: 41).

\subsection{Argument faktičkog stanja}

To je ojačano tvrdnjom da je RS već de facto država, "u izvjesnom smislu već nezavisna" i "sub-suverena" (Parish, 2013: 1, 2) "sub-država" (Ker-Lindsay, 2016: 6). Dodik je u više navrata referisao na standardnu školsku definiciju države, tvrdeći da RS ispunjava sve uslove državnosti koje ta definicija nameće. "Uočio sam da posto-

${ }^{12}$ Ovome izrazito ide u prilog strategija HDZ "treći entitet" koja je konstanta u političkom diskursu Hrvata u BiH (Wybranowski, 2012).

13 "BiH nema svoju teritoriju, jer teritorija pripada Republici Srpskoj i Federaciji BiH. BiH ima samo granice" (Dodik, 2017). 
je tri glavna kriterija da se nešto nazove država, naime: teritorija, efektivna vlast, i narod koji želi državu. Šta nedostaje u Republici Srpskoj? Ništa" (Dodik, 2014). Za razliku od $\mathrm{BiH}, \mathrm{RS}$ ima teritoriju, stanovništvo (pri tome etnički visokohomogeno) i efektivnu vlast: "Budućnost Republike Srpske je odlična. Jedina je samoodrživa i nastaviće da živi, a BiH će se raspasti” (Dodik, 2017).

\subsection{Pravo naroda na samoopredjeljenje i analogija s drugim secesionističkim pokretima u Evropi}

Može se prepoznati jasan pokušaj da se secesionizam u RS tretira kao dio šireg talasa secesionističkih pokreta u Evropi, koji smo opisali u uvodu. Često se pravi konekcija i paralela sa Škotskom, Katalonijom, pa i Flandrijom, gdje je ispoljavanje secesionističkih politika prihvaćeno kao normalno i sastavni je dio programa političkih stranaka (Dodik, 2014; 2017; SNSD, 2013: 16).

Pri tome se ističe voluntaristički pristup međunarodne zajednice, naročito $u$ kontekstu Kosova i raspada bivše SFRJ. Standardno pitanje, visokofrekventno prisutno u političkom diskursu u RS, glasi: "kako oni mogu a mi ne" (Dodik, 2014), te tvrdnja da legitimitet koji je međunarodna zajednica priznala u ovim slučajevima obezbjeđuje isti takav legitimitet i secesionizmu RS (Kecmanović, 2017). Naročito je snažno prisutna analogija s Kosovom (Ker-Lindsay, 2016: 12).

Ako sada pogledamo strukturu i sadržaj ovih argumenata, vidjećemo da secesionizam u RS koristi sve standardne argumente koje smo skicirali u teorijskom pregledu. U tom smislu može se reći da je secesionizam RS teorijski (iznenađujuće) zasnovan i utemeljen te koristi gotovo sve prethodno naznačene teorijske argumentacije.

Argument "liberalni paradoks" možemo pronaći u tvrdnji da se vodeća bošnjačka politička stranka zalaže za stvaranje antidemokratske islamske države. $\mathrm{Na}$ primjer, u Izvještaju upućenom Savjetu bezbjednosti UN, pod naslovom "SDA je islamistička stranka", navodi se sljedeće: "Alija Izetbegović, prvi predsjednik $\mathrm{BiH}$ i otac aktuelnog lidera SDA je i autor Islamske deklaracije u kojoj se kaže da nije moguća koegzistencija između islama i neislamskih društvenih i političkih institucija, te da je dugoročni politički cilj SDA stvaranje islamske države, i nemogućnost njene koegzistencije s neislamskim zajednicama i sekularnim institucijama" (XVI izvještaj RS, 2016: 11). U tom kontekstu skreće se pažnja na problem džihadista i uspona radikalnog islama (vehabija i selefija) u BiH (ibid.: 10). Tvrdi se da Srbi ne žele da žive u takvom društvu (ibid.) i stoga je stvar bazičnih liberalnih principa dopustiti ovim zajednicama da se razdvoje, jer, kako je to gore rečeno, a i prema riječima samog Alije Izetbegovića, nije moguća mirna koegzistencija u zajedničkoj državi. U tom smislu ovaj argument se preklapa s argumentom "očuvanja kultura". 
Argument "ograničeni cilj političkog udruživanja" je prisutan u sljedećoj formi: sami bošnjački politički predstavnici forsiraju tezu da je "Dejton donio mir, ali ne i političku stabilnost". Taj "ograničeni” politički cilj (mir) je realizovan i dejtonska tvorevina $\mathrm{BiH}$ više nema razloga ni svrhe da postoji. Strane potpisnice DMS, tj. RS i FBiH treba da se sada mirno razdruže i eventualno formiraju neku novu političku zajednicu (Deklaracija SNSD, 2015: 7).

Argument "učiniti ulazak lakšim" eksplicitno je prisutan u inicijativi za novi Ustav RS koji bi sadržavao klauzulu o pravu na secesiju. Kada se tvrdi da je BiH "kreacija međunarodne zajednice", tada se tvrdi za ovaj argument važna nijansa da je u pitanju "eksperimentalna zajednica". Prihvatanje klauzule o secesiji bitno bi relaksiralo odnose u $\mathrm{BiH}$.

Argument "diskriminatorna redistribucija” je široko prisutan i jedna je od glavnih strategija u prilog secesije izrazito prisutna u političkom diskursu, a prethodno smo već naznačili osnovne konkretne argumente iz ove klase.

Argument "povećanje efikasnosti" se odnosi na tvrdnju da je BiH iracionalna s ekonomske tačke gledišta te da u njoj svi gube, a RS naročito. Na primjer, tvrdi se da RS prednjači u provedbi neophodnih reformi te da je koče $\mathrm{FBiH}$ i BiH (XV izvještaj RS, 2016: 3-5). Razdvajanje bi stvorilo efikasnije i racionalnije političke zajednice.

Argument "samoopredjeljenje" je, kako smo vidjeli, takođe široko primjenjivana strategija, koja se odnosi na pravo srpskog naroda u BiH na samoopredjeljenje do otcjepljenja i pravi se analogija s drugim situacijama u kojima je to pravo bilo priznato, poput Kosova, Crne Gore i Ukrajine. To je takođe povezano s argumentom "pristanka".

Argument "očuvanje kultura" se povremeno pojavljuje u kontekstu činjenice da je etnička slika BiH takva da oko 50\% čine muslimani-Bošnjaci. Često se pravi paralela s iskustvom Hrvata u Federaciji BiH, koji u više navrata trpe otvorenu ili prikrivenu diskriminaciju od strane većinskih Bošnjaka. Karakteristični primjeri su nemogućnost Hrvata da uspostave TV kanal na hrvatskom jeziku i izbor Željka Komšića za hrvatskog člana Predsjedništva BiH. Logika argumentacije je sljedeća: s obzirom na to da je $\mathrm{BiH}$ nemoguća u ovoj formi te da projekt unitarizacije vodi ka diskriminaciji od strane većinskih Bošnjaka, kako to pokazuje iskustvo Hrvata u FBiH, secesija je stvar opstanka kulture i samobitnosti brojčano manjih naroda.

Argument rektifikacijske pravde je takođe često primjenjivana strategija i odnosi se na osporavanje legitimnosti referenduma o nezavisnosti BiH iz 1992. godine. 


\subsection{Argumenti protiv secesije}

Prije nego iz svega navedenog pokušamo izvući relevantne zaključke korisno je osvrnuti se na argumente protiv secesionizma RS, a koji konvergiraju prethodno opisanim secesionističkim strategijama. Tako se argument "nelegitimnosti" $\mathrm{BiH}$ pobija upravo suprotnom tvrdnjom: referendum o nezavisnosti $\mathrm{BiH}$ bio je priznat od strane međunarodne zajednice, dok je "plebiscit srpskog naroda" proglašen nelegalnim. Argumenti o "neefikasnosti” se osporavaju tvrdnjom: uzrok za neefikasnost i zastoje BiH su upravo secesionističke politike RS i svjesne zloupotrebe blokada koje im dopušta postojeći “dejtonski” Ustav BiH. Zato, umjesto odvajanja jednog entiteta, treba ići u pravcu ustavne revizije koja bi centralizovala državu i onemogućila takve blokade. Argument faktičkog stanja se osporava s legitimacijske tačke: premda RS jeste etnički homogena teritorija, to je "rezultat etničkog čišćenja i genocida". Time se delegitimira tvrdnja o državnim atributima RS (Ker-Lindsay, 2016: 10) i tvrdnja da je RS de facto već država. Čak i da to jeste tako, tvrdi se da je to "genocidna tvorevina".

Posebno se naglašava prijetnja nestabilnosti i čak rata u slučaju forsiranja nezavisnosti RS (ibid.: 13). S obzirom na prethodno, secesija RS "nikada neće biti prihvaćena od strane Bošnjaka” i na tu vrstu opasnosti je upozorio i OHR (OHR Report 50, 2016: 5). Ovo je svakako ozbiljan izazov za secesioniste u RS. Međutim, neka novija istraživanja dovode u sumnju neprikosnovenost ovog scenarija. Na primjer, na pitanje: "Koju biste od ovih akcija bili voljni preduzeti da osigurate integritet $\mathrm{BiH}$ ili da spriječite secesiju njene teritorije?" samo je mali procenat ispitanika dao odgovor da bi pribjegao nasilju i/ili oružju. Tako je od ispitanika starosne dobi 18-35 godina njih 4,2\% izjavilo da bi pribjeglo nasilju, a 2,3\% da bi "uzelo oružje", dok je čak $43 \%$ njih reklo da se uopšte ne bi angažovalo, a 46,6\% da bi učestvovalo samo u nenasilnim protestima (Prism Research, 2015: 52). Slični su rezultati i za ostale starosne skupine. Kada se pogleda nacionalna struktura, vidimo da bi u slučaju secesije RS tek 5,9\% Bošnjaka učestvovalo u nasilnim protestima, a 4,3\% bi "uzelo oružje" (ibid.: 51). Isto tako, tek 1,7\% Srba bi bilo voljno da secesiju RS podrži "uzimanjem oružja" (ibid.: 65). Očito, ima osnova u stavu da, unatoč militantnoj antisecesionističkoj retorici bošnjačkih političara, nije jasno da bi oni bili u stanju mobilisati svoje stanovništvo na ozbiljniji oružani otpor secesiji RS (Parish, 2013: 6).

Važan argument protiv secesije je tvrdnja da je ona, čak u idealnom scenariju, zapravo apsurdna i besmislena politika. Čak i da se nezavisnost RS realizuje, tako nastali politički subjekt ne bi mogao računati na šire međunarodno priznanje i bio bi sveden na ilegalan status kakav ima npr. Južna Osetija, Abhazija (Ker-Lindsay, 2016: 19-22) i druge "crne rupe na međunarodnoj karti” (Parish, 2013: 2). Kosovski presedan ne može biti efikasan obrazac, jer RS nema iza sebe podršku SAD i veli- 
ke većine EU, kako je to bilo u slučaju Kosova (Wybranowski, 2012). Važnije od ovoga argumenta geopolitičke moći je da su i pravni aspekti ovih slučajeva različiti. Jednostrana secesija prihvatljiva je samo u slučaju drastičnog kršenja i nepoštovanja prava, a to ne može biti prihvaćeno u slučaju BiH koja je pod ingerencijom svih relevantnih dokumenata i rezolucija koje definišu tu materiju. Takođe, kao što je poznato, Badinterova komisija je proglasila raspad Jugoslavije kao slučaj “disolucije", ne secesije. Nakon toga, dala je mišljenje po kome Srbima u Hrvatskoj i BiH ne može biti priznato pravo na secesiju jer te države prihvataju i poštuju međunarodne standarde o ljudskim pravima, zaštitu manjina itd. (Oellers-Frahm, 2005: 199-200).

Prema tome, čak i da se secesija realizuje, ona je apsurdna: "U najboljem slučaju, scenario koji bi se dogodio je nepriznat entitet, međunarodno izolovan i mnogo osiromašeniji nego je sada" (Kartsonaki, 2016: 504). Sa svim negativnim posljedicama koje to znači i gubitkom svih privilegija koje sada RS crpi na osnovu svog postojanja u $\mathrm{BiH}$ kao međunarodno priznatoj državi, poput na primjer slobodnog kretanja bez viza u Šengen zoni. Ovo je jedan od argumenata koji na direktan način pobija argument "diskriminacije" u secesionističkim strategijama (Parish, 2013: 2-3). Snažna izolacija RS praćena sankcijama je izvjestan scenario u slučaju proglašenja nezavisnosti (Ker-Lindsay, 2016: 43). Razlozi za takvo odbijanje priznavanja nezavisnosti RS su mnogobrojni i različiti. Od toga da bi priznavanje značilo prima facie priznanje neuspjeha decenijskog projekta izgradnje $\mathrm{BiH}$ države od strane EU i SAD, te značilo priznanje da su milijarde dolara "bačene" bez ikakvog efekta, a jednako veliki je i politički kapital koji je u tom periodu investiran u BiH (ibid.: 17; Parish, 2013: 3). Takođe, time bi se dogodio neželjeni scenario nastanka nove "muslimanske" države u središtu Evrope (Parish, 2013: 3). Vjerovatno je da ni Rusija (ibid.; Ker-Lindsay, 2016: 18-21), a ni Srbija (Ker-Lindsay, 2016: 35-36) ne bi podržale nezavisnost: obe imaju vlastite probleme secesionizma, i za obe države bi to značilo daljnju konfrontaciju sa Zapadom, uz poznate scenarije sankcija, ograničenja kretanja itd. U novijim istraživanjima skrenuta je pažnja na važnu, i možda odlučujuću ulogu takve podrške nekog od igrača na međunarodnoj ili regionalnoj sceni za uspjeh unilaterano proglašene secesije (ibid.: 31-32). Poseban argument iz klase iracionalnosti secesije je teza o "geografskoj specifičnosti RS": sam pogled na kartu RS pokazuje da je to nelogična teritorijalna jedinica (Parish, 2013: 3-4) koja bi teško profunkcionisala. Pri tome podijeljena na dva dijela distriktom Brčko. U slučaju secesije, zapadni dio RS bi bio praktično odsječen bez mogućnosti da se dugotrajno održi (Ker-Lindsay, 2016: 44). ${ }^{14}$

14 Ova se geografska iracionalnost tako nastale države može donekle prevladati ujedinjenjem sa Srbijom. Međutim, to nije željena opcija, jer znači suštinsku redukciju moći političkih elita RS (Wybranowski, 2012). 
$\mathrm{Na}$ osnovu snage ovih argumenata protiv nezavisnosti mnogi su na stanovištu da je secesionistička retorika zapravo lažna opcija i puki dnevnopolitički spin: "sigurno je da se Bosna i Hercegovina suočava s mnogim problemima. Ipak, secesiju Republike Srpske ne bi trebalo uzeti kao jedan od njih" (ibid.: 53).

\section{Zaokret 2017/2018?}

U periodu 2017-2018. došlo je do izvjesnog, možda radikalnog, zaokreta u secesionističkoj retorici onih koji su do sada bili označeni kao glavni propagatori te politike. Na primjer, Dodik (2017) je u jednom od osvrta na secesionizam RS rekao sljedeće: "Secesija Republike Srpske je tek potencijalni odgovor na kršenje Dejtonskog sporazuma ... RS nije donijela nijednu odluku koja se bavi pitanjem secesije, premda secesija kao politička tema postoji i postojaće.” Ističe se da je privrženost Dejtonskom sporazumu jasno naglašena u ključnim dokumentima SNSD, Političkom programu pa čak i u Statutu stranke (član 3), kao i u mnogim drugim dokumentima koje je stranka objavila (SNSD, 2013: 38). Posebno je naglašena činjenica da RS nije institucionalizovala politiku secesije (Dodik, 2017). Čak se i sporna Deklaracija intepretira na ne-secesionistički način: tvrdi se da termin "nezavisnost" u Deklaraciji nije upotrebljen kao proklamacija "političke nezavisnosti”, već "kulturne autonomije" i ukazuje da se u Deklaraciji nedvosmisleno iskazuje "odanost dejtonskom poretku BiH".

Ako se ovdje zaista događa neki zaokret, postavlja se pitanje njegovih uzroka. Da li su u pitanju sankcije koje su SAD uvele prema Predsjedniku RS $?^{15} \mathrm{U}$ tom slučaju radi se o povlačenju iz taktičkih razloga: daljnje insistiranje na secesiji bi naprosto bilo "diplomatsko samoubistvo" u ovom momentu (Parish, 2013: 4). Kompletna prethodno opisana argumentacija i strategija za nezavisnost ostaje i dalje na dnevnom redu, ali je trenutno stavljena ad acta iz čisto taktičkih razloga. ${ }^{16}$ Ili "zaokret" predstavlja samo pojašnjenje pozicije i politika koje su zapravo uvijek bile takve, tj. nikakvog zaokreta ovdje niti nema: RS, SNSD i Dodik su uvijek bili za poštovanje DMS, a BiH je na osnovu DMS priznata kao država? Prijetnja secesijom je striktno defanzivna politika koja treba "drugu stranu" upozoriti na moguće posljedice daljnjeg narušavanja dejtonskog balansa i pokušaja majorizacije dva manja konstitutivna naroda.

15 Takvo je stanovište zauzeo npr. OHR (OHR Report 51, 2017: 1b). Ublažavanje secesionističke retorike kao posljedica sankcija se jasno navodi i u narednom izvještaju (OHR Report 52, 2017: 1). 16 Pojedini komentari čini se da govore tome u prilog. Na primjer Dodik je u junu 2017. dao sljedeći komentar: "Mi nećemo organizovati referendum o secesiji u 2018. ... Mi razumijemo okolnosti, kontekst. Referendum u 2018. proizveo bi mnogobrojne reakcije i mi još uvijek želimo da gradimo momentum za legitimaciju toga kao našeg prava ... Da li će neke od narednih godina podići to pitanje, vidjećemo, ne znam" (Dodik, 2017). 


\section{Zaključak}

Na osnovu prethodno prikazanog možemo formulisati sljedeće zaključke. Secesionistička retorika je u RS prisutna konstantno od samog početka njenog postojanja, a u periodu od 2006. do 2018. je snažno intenzivirana. Pri tome je stav javnosti konstantno "Za", premda se na osnovu dostupnih podataka čini da je intenzitet podrške u tendenciji opadanja. Društveni pokreti koji ovu politiku podržavaju i dalje su minorni i nije formiran jak društveni front koji bi nosio politiku secesije. Separatizam je relativno dobro zasnovan i u mnogome kompatibilan s drugim secesionističkim pokretima. Nije, dakle, nikakav eksces, već slijedi matrice i argumente drugih secesionističkih pokreta kao i njihove političkoteorijske interpretacije. Na političkoj sceni uglavnom je nošen od političke stranke SNSD i njenog lidera Milorada Dodika. Secesionizam nije institucionalizovan i zvanične institucije RS gotovo da ni ne referišu na tu temu. Naprotiv, kako to pokazuju izvještaji RS prema UN, privrženost poštovanju DMS i “dejtonske" BiH je konstanta i ekplicitno iskazana politička pozicija RS. Ipak, bilo bi ishitreno zaključiti (na osnovu činjenice da secesionizam nosi jedna stranka i da nije institucionalizovana politika) da je u pitanju dnevnopolitička propaganda i "predizborna" strategija. Kontinuitet secesionističkih iskaza pokazuje da je u pitanju neka vrsta strateške orijentacije. Secesionistička retorika se ne događa s vremena na vrijeme i ad hoc, na primjer u periodima predizbornih kampanja, već je konstantno prisutna u retorici određenih političkih aktera. Gotovo identične izjave za nezavisnost mogu se vidjeti u rasponu od petnaest godina. Ako prihvatimo da nije u pitanju dnevnopolitički spin, već dugoročno prisutna, premda neinstitucionalizovana politika (ili bar retorika), naš zadatak je da razumijemo svrhu i domete te politike.

Iz činjenica (i) da je secesionizam intenziviran u periodu nakon 2006., tj. nakon radikalne unitarističke kampanje tadašnjih vodećih bošnjačkih političara (Harisa Silajdžića i Stranke za BiH) i političke platforme " $100 \%$ BiH"; (ii) da nije institucionalizovan, već je nošen od strane jedne političke stranke i njenog lidera; i (iii) da oficijelni stavovi institucija RS eksplicitno podržavaju DMS i “dejtonsku” BiH čini se da najviše osnova ima za interpretaciju koja secesionističku retoriku u RS vidi kao defanzivnu i profilaktičku mjeru protiv antidejtonskih politika koje se s vremena na vrijeme pojavljuju, prije svega od strane političkih predstavnika Bošnjaka. Aleksandar Vranješ je o tome rekao:

Secesija nije zvanična politika niti Vlade, niti Narodne Skupštine RS, nema nijednog zvaničnog dokumenta institucija Republike Srpske koji propisuju takvu politiku... secesija je moguća opcija, ali samo u slučaju daljih narušavanja i nastavka negiranja ustavnih pozicija Republike Srpske koje su propisane međunarodnim ugovorom kakav je Dejtonski sporazum. Dakle, to se u javnosti može čuti kao po- 
tencijalni i defanzivni plan, a nikako kao zvanična i ofanzivna politika po pitanju državnosti BiH (RTRS, 2018).

Unatoč ponekad agresivnoj retorici, i unatoč činjenici da nesumnjivo proizvodi manje ili više snažne političke krize, radi se zapravo o defanzivnoj agendi, koja je u funkciji očuvanja postojećeg ustavnopravnog poretka, premda se svojom formom i jezikom koji koristi čini kao negacija istog. Dominantan politički stav o secesiji RS, koji su kreirali SNSD i M. Dodik u periodu 2006-2018, jeste nesumnjivo pro-secesionistički u smislu prava srpskog naroda na samostalnost, ali to je striktno kondicionalni stav u formi "ako...". Upravo zato i nije institucionalizovan, i činjenica neinstitucionalizovanosti dominantnog političkog stava o secesiji je dokaz njegove kondicionalnosti. To nije pretočeno u pravno obavezujuće tekstove, već je prisutno kao deklarativna proklamacija političkog prava. Generalni zaključak ovog teksta može biti podržan i na osnovu selektivnog teorijskog okvira i argumentacija koje koriste protagonisti secesionizma RS. Naime, premda variraju različite teorijske argumentacije popularne i u drugim secesionističkim pokretima trenutno prisutnim u Evropi, upadljivo nedostaje ključni argument saglasnosti/pristanka. S obzirom da je to i najpopularniji argument u prilog secesije, a istovremeno ga podržava i praksa uspješnih secesionizama, na stanovištu smo da njegovo ignorisanje može biti protumačeno kao prima facie dokaz da je u pitanju "prazna" prijetnja, a ne stvarna agenda. Proaktivna dimenzija secesionizma pojavljuje se tek kao kontekst prognoze o neodrživosti sadašnje $\mathrm{BiH}$ i poželjni scenario (određenih političkih aktera, a takođe i još uvijek većinskog dijela javnosti) koji u slučaju njenog raspada slijedi. Sama secesionistička retorika, međutim, nije suštinski uzrok nestabilnosti i/ili neodrživosti $\mathrm{BiH}$, i u tom smislu se može prihvatiti ocjena o "praznoj" prijetnji koju je dao Ker-Lindsay. Štaviše, može se reći da je profilaktički karakter secesionističke retorike RS jedna vrsta insistiranja na poštovanju "pristanak kriterija" i kontraktualističkoj teoriji secesije. Naime, kada RS prijeti secesijom, ali kondicionalno: "ako" druga strana u ugovoru nastavi da ne poštuje i izvrgava bazični politički ugovor, onda se može reći da je to zapravo kredibilna strategija koja radi na očuvanju postojećeg konsenzusa, a ne sredstvo njegove razgradnje. Prema tome, ako se prethodna dijagnoza o prirodi i svrsi secesionističke retorike u RS može prihvatiti kao stvarna agenda i intencija protagonista secesionizma RS, onda se sa stanovišta osnovne teorijske orijentacije autora ovog teksta to mora priznati kao legitiman metod. 


\section{LITERATURA}

Agnieli, Oliviero. 2015. Cosmopolitanism, Self-Determination and Territory. Palgrave Macmillan. New York.

Ashdown, Paddy i Holbrooke, Richard. 2008. A Bosnian powder keg. The Guardian. Dostupno na https://www.theguardian.com/commentisfree/2008/oct/22/ashdownholbrooke-bosnia-balkan-dayton. Pristupljeno 1. 10. 2019.

Bartkus, Viva. 1999. The Dynamic of Secession. Cambridge University Press. Cambridge.

Beran, Harry. 1998. A Democratic Theory of Political Self-Determination for a New World Order, u: Percy B. Lehning (ur.): Theories of Secession. Routledge. New York: 32-59.

Bishai, Linda. 1998. Altered states - Secession and the problems of liberal theory, u: Percy B. Lehning (ur.): Theories of Secession. Routledge. New York: 91-108.

BTI. 2003. The Bertelsmann Stiftung - Transformation Index (BTI) - Bosnia and Herzegovina Country Report. Dostupno na https://www.bti-project.org/fileadmin/files/ BTI/Downloads/Reports/2003/pdf/BTI_2003_Bosnia_and_Herzegovina.pdf. Pristupljeno 27. 12. 2018.

BTI. 2006. The Bertelsmann Stiftung - Transformation Index (BTI) - Bosnia and Herzegovina Country Report. Dostupno na https://www.bti-project.org/fileadmin/files/ BTI/Downloads/Reports/2006/pdf/BTI_2006_Bosnia_and_Herzegovina.pdf. Pristupljeno 27. 12. 2018.

BTI. 2008. The Bertelsmann Stiftung - Transformation Index (BTI) - Bosnia and Herzegovina Country Report. Dostupno na https://www.bti-project.org/en/reports/country-reports/detail/itc/bih/ity/2008/itr/ecse/. Pristupljeno 27. 12. 2018.

BTI. 2010. The Bertelsmann Stiftung - Transformation Index (BTI) - Bosnia and Herzegovina Country Report. Dostupno na https://www.bti-project.org/en/reports/country-reports/detail/itc/bih/ity/2010/itr/ecse/. Pristupljeno 27. 12. 2018.

BTI. 2012. The Bertelsmann Stiftung - Transformation Index (BTI) - Bosnia and Herzegovina Country Report. Dostupno na https://www.bti-project.org/en/reports/country-reports/detail/itc/bih/ity/2012/itr/ecse/. Pristupljeno 27. 12. 2018.

BTI. 2014. The Bertelsmann Stiftung - Transformation Index (BTI) - Bosnia and Herzegovina Country Report. Dostupno na https://www.bti-project.org/en/reports/country-reports/detail/itc/bih/ity/2014/itr/ecse/. Pristupljeno 27. 12. 2018.

BTI. 2016. The Bertelsmann Stiftung - Transformation Index (BTI) - Bosnia and Herzegovina Country Report. Dostupno na https://www.bti-project.org/en/reports/country-reports/detail/itc/bih/ity/2016/itr/ecse/. Pristupljeno 27. 12. 2018.

BTI. 2018. The Bertelsmann Stiftung - Transformation Index (BTI) - Bosnia and Herzegovina Country Report. Dostupno na https://www.bti-project.org/en/reports/country-reports/detail/itc/bih/ity/2018/itr/ecse/. Pristupljeno 27. 12. 2018. 
Buchanan, Allen. 1991. Secession. Westview Press. San Francisco.

Chen, Yan i Ordeshook, Peter C. 1994. Constitutional Secession Clause. Constitutional Political Economy, (5), 1: 45-60.

Communiqué of the Steering Board of the Peace Implementation Council. 2015. Dostupno na http://www.ohr.int/?p=68880. Pristupljeno 22. 10. 2019.

Costa, Josep. 2003. On theories of secession: minorities, majorities and the multinational state. Critical Review of International Social and Political Philosophy, (6), 2: 63-90.

Deklaracija SNSD. 2015. Republika Srpska - Slobodna i samostalna budućnost i odgovornost. 25. april 2015. godine. Dostupno na http://snsd.org/images/dokumenti/deklaracija-predsjednik.pdf. Pristupljeno 8. 10. 2019.

Dodik, Milorad. 2014. Secesionistički pokreti u Škotskoj i Kataloniji mogu da pomognu $R S$. Dostupno na https://www.blic.rs/vesti/politika/dodik-za-njuzvik-secesionisticki-pokreti-u-skotskoj-i-kataloniji-mogu-da-pomognu-rs/2hscc0v. Pristupljeno 15. 5. 2018.

Dodik, Milorad. 2017. Official: there will be no Referendum in the RS! Sarajevo Times. Dostupno na https://www.sarajevotimes.com/official-will-no-referendum-rs. Pristupljeno 27. 12. 2018.

European Parliament Resolution. 2016. European Parliament Resolution of 14 April 2016 on the 2015 Report on Bosnia and Herzegovina (2015/2897(RSP). Dostupno na http://www.europarl.europa.eu/doceo/document/TA-8-2016-0135 EN.html?redirect. Pristupljeno 21. 10. 2019.

Freeman, Michael. 1998. The priority of function over structure: a new approach to secession, u: Percy B. Lehning (ur.): Theories of Secession. Routledge. New York: 13-31.

Gallup Balkan Monitor. 2010. Focus on Bosnia and Herzegovina. Dostupno na www. balkan-monitor.eu/files/Gallup_Balkan_Monitor-Focus_On_Bosnia_and_Herzegovina.pdf. Pristupljeno 27. 6. 2013.

Hoppe, Hans-Hermann. 1998. The Future of Liberalism - A Plea For A New Radicalism. Polis (3), 1. Dostupno na http://www.hanshoppe.com/wp-content/uploads/publications/hoppe-plea.pdf. Pristupljeno 21. 10. 2019.

Kartsonaki, Argyro. 2016. Twenty years after Dayton: Bosnia-Herzegovina (still) stable and explosive. Civil Wars, (18), 4: 488-516.

Kasapović, Mirjana. 2005. Bosna i Hercegovina: podijeljeno društvo i nestabilna drža$v a$. Politička kultura. Zagreb.

Kecmanović, Nenad. 2017. Secesija Kosova od Srbije daje legitimitet Srpskoj da ode iz BiH. Glas Srpske. Dostupno na https://www.glassrpske.com/lat/novosti/vijesti dana/Kecmanovic-Secesija-Kosova-od-Srbije-daje-legitimitet-Srpskoj-da-ode-izBiH/250115. Posjećeno 19. 10. 2019. 
Ker-Lindsay, James. 2016. The hollow threat of secession in Bosnia and Herzegovina: legal and political impediments to a unilateral declaration of independence by Republika Srpska. LSEE - Research on South Eastern Europe. London.

Lefkowitz, David. 2008. On the Foundation of Rights to Self-Determination: Secession, Nonintervention, and Democratic Governance. Journal of Social Philosophy, (39), 4: 492-511.

Lehning, Percy B., ur. 1998. Theories of Secession. Routledge. New York.

Mackenzie, Rice. 2017. Building a State From a Broken Nation: The Case of BosniaHerzegovina. Towson University of international affairs, (50), 2: 1-15.

Mises, Ludwig. 1985. Liberalism. Cobden Press. San Francisco.

Mitrović, Slavko. 2018. Ustavna perspektiva. Argumenti, (33): 197-209.

Moltchanova, Anna. 2009. National Self-Determination and Justice in Multinational States. Springer. New York.

Narodna skupština Republike Srpske. 2008. Rezolucija o nepriznavanju jednostrano proglašene nezavisnosti Kosova i Metohije i opredjeljenjima Republike Srpske. Dostupno na https://www.narodnaskupstinars.net/?q=la/akti/ostali-akti/rezolucija-onepriznavanju-jednostrano-proglašene-nezavisnosti-kosova-i-metohije-i-opredjeljenjima-republike-srpske. Posjećeno 4. 5. 2018.

New York Times. 2018. In a New Cold War With Russia, Balkans Become a Testing Ground. The New York Times. Dostupno na https://www.nytimes.com/2018/04/10/ world/europe/european-union-balkans.html. Pristupljeno 11. 10. 2019.

Nezavisne novine. 2015. Anketa: Više od polovine ispitanika za samostalnost RS, vole Dodika, a vjeruju crkvi. Dostupno na http://www.nezavisne.com/novosti/BiH/ Anketa-Vise-od-polovine-ispitanika-za-samostalnost-RS-vole-Dodika-a-vjerujucrkvi/319950. Pristupljeno 22. 10. 2019.

Noack, Rick. 2017. Europe has plenty of secessionist movements like Catalonia. Most don't want full independence, though. The Washington Post. Dostupno na https:// www.washingtonpost.com/news/worldviews/wp/2017/10/11/europe-has-many-independence-movements-apart-from-catalonia-few-of-them-want-full-self-determination. Pristupljeno 11. 10. 2019.

Nossiter, Adam. 2017. Is Corsica the Next Catalonia? Nationalists Are Poised for Election Win. The New York Times. Dostupno na https://www.nytimes.com/2017/12/01/ world/europe/corsica-catalonia-independence.html. Pristupljeno 1. 10. 2019.

Oellers-Frahm, Karin. 2005. Restructuring Bosnia-Herzegovina: A Model with Pit-Falls. Max Planck Yearbook of United Nations Law, (9): 179-224.

OHR Report 5. 1997. 5th Report of the High Representative for Implementation of the Peace Agreement on BiH to the Secretary-General of the UN. Dostupno na http:// www.ohr.int/?p=57299. Pristupljeno 29. 10. 2019. 
OHR Report 14. 1999. 14th Report of the High Representative for Implementation of the Peace Agreement on BiH to the Secretary-General of the UN. Dostupno na http:// www.ohr.int/?p=57263. Pristupljeno 29. 10. 2019.

OHR Report 22. 2002. 22nd Report of the High Representative for Implementation of the Peace Agreement on BiH to the Secretary-General of the UN. Dostupno na http://www.ohr.int/22nd-report-by-the-high-representative-for-implementation-ofthe-peace-agreement-to-the-secretary-general-of-the-united-nations/. Pristupljeno 29. 10. 2019.

OHR Report 23. 2002. 23rd Report of the High Representative for Implementation of the Peace Agreement on BiH to the Secretary-General of the UN. Dostupno na http:// www.ohr.int/?p=49968. Pristupljeno 29. 10. 2019.

OHR Report 28. 2005. 28th Report of the High Representative for Implementation of the Peace Agreement on BiH to the Secretary-General of the UN. Dostupno na http:// www.ohr.int/?p=42439. Pristupljeno 29. 10. 2019.

OHR Report 30. 2006. 30th Report of the High Representative for Implementation of the Peace Agreement on BiH to the Secretary-General of the UN. Dostupno na http:// www.ohr.int/?p=40435. Pristupljeno 29. 10. 2019.

OHR Report 31. 2007. 31st Report of the High Representative for Implementation of the Peace Agreement on BiH to the Secretary-General of the UN. Dostupno na http:// www.ohr.int/?p=39119. Pristupljeno 29. 10. 2019.

OHR Report 32. 2007. 32nd Report of the High Representative for Implementation of the Peace Agreement on BiH to the Secretary-General of the UN. Dostupno na http:// www.ohr.int/?p=38182. Pristupljeno 29. 10. 2019.

OHR Report 33. 2008. 33rd Report of the High Representative for Implementation of the Peace Agreement on BiH to the Secretary-General of the UN. Dostupno na http:// www.ohr.int/?p=37452. Pristupljeno 29. 10. 2019.

OHR Report 34. 2008. 34th Report of the High Representative for Implementation of the Peace Agreement on BiH to the Secretary-General of the UN. Dostupno na http:// www.ohr.int/?p=36616. Pristupljeno 29. 10. 2019.

OHR Report 35. 2009. 35th Report of the High Representative for Implementation of the Peace Agreement on BiH to the Secretary-General of the UN. Dostupno na http:// www.ohr.int/?p=35967. Pristupljeno 29. 10. 2019.

OHR Report 36. 2009. 36th Report of the High Representative for Implementation of the Peace Agreement on BiH to the Secretary-General of the UN. Dostupno na http:// www.ohr.int/?p=35210. Pristupljeno 29. 10. 2019.

OHR Report 37. 2010. 37th Report of the High Representative for Implementation of the Peace Agreement on BiH to the Secretary-General of the UN. Dostupno na http:// www.ohr.int/?p=34492. Pristupljeno 29. 10. 2019. 
OHR Report 38. 2010. 38th Report of the High Representative for Implementation of the Peace Agreement on BiH to the Secretary-General of the UN. Dostupno na http:// www.ohr.int/?p=32154. Pristupljeno 29. 10. 2019.

OHR Report 39. 2011. 39th Report of the High Representative for Implementation of the Peace Agreement on BiH to the Secretary-General of the UN. Dostupno na http:// www.ohr.int/?p=33514. Pristupljeno 29. 10. 2019.

OHR Report 40. 2011. 40th Report of the High Representative for Implementation of the Peace Agreement on BiH to the Secretary-General of the UN. Dostupno na http:// www.ohr.int/?p=33143. Pristupljeno 29. 10. 2019.

OHR Report 41. 2012. 41st Report of the High Representative for Implementation of the Peace Agreement on BiH to the Secretary-General of the UN. Dostupno na http:// www.ohr.int/?p=32771. Pristupljeno 29. 10. 2019.

OHR Report 42. 2012. 42nd Report of the High Representative for Implementation of the Peace Agreement on BiH to the Secretary-General of the UN. Dostupno na http:// www.ohr.int/?p=32530. Pristupljeno 29. 10. 2019.

OHR Report 43. 2013. 43rd Report of the High Representative for Implementation of the Peace Agreement on BiH to the Secretary-General of the UN. Dostupno na http:// www.ohr.int/?p=32286. Pristupljeno 29. 10. 2019.

OHR Report 44. 2013. 44th Report of the High Representative for Implementation of the Peace Agreement on BiH to the Secretary-General of the UN. Dostupno na http:// www.ohr.int/?p=32012. Pristupljeno 29. 10. 2019.

OHR Report 45. 2014. 45th Report of the High Representative for Implementation of the Peace Agreement on BiH to the Secretary-General of the UN. Dostupno na http:// www.ohr.int/?p=31718. Pristupljeno 29. 10. 2019.

OHR Report 46. 2014. 46th Report of the High Representative for Implementation of the Peace Agreement on BiH to the Secretary-General of the UN. Dostupno na http:// www.ohr.int/?p=31320. Pristupljeno 29. 10. 2019.

OHR Report 47. 2015. 47th Report of the High Representative for Implementation of the Peace Agreement on BiH to the Secretary-General of the UN. Dostupno na http:// www.ohr.int/?p=31099. Pristupljeno 29. 10. 2019.

OHR Report 48. 2015. 48th Report of the High Representative for Implementation of the Peace Agreement on BiH to the Secretary-General of the UN. Dostupno na http:// www.ohr.int/?p=63204. Pristupljeno 29. 10. 2019.

OHR Report 49. 2016. 49th Report of the High Representative for Implementation of the Peace Agreement on BiH to the Secretary-General of the UN. Dostupno na http:// www.ohr.int/?p=69005. Pristupljeno 29. 10. 2019.

OHR Report 50. 2016. 50th Report of the High Representative for Implementation of the Peace Agreement on BiH to the Secretary-General of the UN. Dostupno na http:// www.ohr.int/?p=96460. Pristupljeno 29. 10. 2019. 
OHR Report 51. 2017. 51st Report of the High Representative for Implementation of the Peace Agreement on BiH to the Secretary-General of the UN. Dostupno na http:// www.ohr.int/51 st-report-of-the-high-representative-for-implementation-of-the-peace-agreement-on-bosnia-and-herzegovina-to-the-secretary-general-of-the-unitednations/. Pristupljeno 29. 10. 2019.

OHR Report 52. 2017. 52nd Report of the High Representative for Implementation of the Peace Agreement on BiH to the Secretary-General of the UN. Dostupno na http:// www.ohr.int/?p=98165. Pristupljeno 29. 10. 2019.

OHR Report 53. 2018. 53rd Report of the High Representative for Implementation of the Peace Agreement on BiH to the Secretary-General of the UN. Dostupno na http:// www.ohr.int/?p=99230. Pristupljeno 29. 10. 2019.

Parish, Matthew. 2013. Bosnian Serb Secession: Could it Ever Happen? Dostupno na http://www.transconflict.com/2013/05/bosnian-serb-secession-could-it-ever-happen-075/. Pristupljeno 27. 4. 2017.

Pavković, Aleksandar i Radan, Petar. 2007. Creating new states: theory and practice of secession. Ashgate Publishing Limited. Hampshire.

Prism Research. 2015. The Public Opinion Poll Results for Office of the UN Resident Coordinator. Dostupno na http://www.undp.org/content/dam/unct/BiH/PDFs/Prism\%20Research\%20for\%20UN\%20RCO_Report.pdf. Pristupljeno 24. 11. 2018.

Reuters. 2017. U.S. imposes sanctions on Bosnian Serb nationalist leader Dodik. Dostupno na https://www.reuters.com/article/us-usa-sanctions-bosnia-dodik/u-s-imposes-sanctions-on-bosnian-serb-nationalist-leader-dodik-idUSKBN1512WI. Pristupljeno 20. 10. 2019.

RTRS. 2018. Šta se krije iza plana da se Srpska optuži za secesiju, dok Bakir gomila oružje?! Dostupno na http://lat.rtrs.tv/vijesti/vijest.php?id=297802. Posjećeno 20. 7. 2019.

Savanović, Aleksandar. 2017. Problem diskrecionog ovlaštenja: Da li je Ustavni sud BiH “politički sud”? Politeia, (8), 14: 63-79.

Savanović, Aleksandar. 2018. "Venexit" - Veneto secession movement. Politeia, (8), 15: 32-49.

Savanović, Aleksandar. 2019. Teorija Republike. Fakultet političkih nauka. Banja Luka.

Savic, Misha i Filipovic, Gordana. 2017. "Europe's Next Separatist Time Bomb Is Ticking". Bloomberg. Dostupno na https://www.bloomberg.com/news/articles/2017-11-16/europe-s-next-separatist-time-bomb-is-ticking-in-the-balkans. Pristupljeno 28. 10. 2018.

Security Council Report. 2017. Dostupno na https:/www.securitycouncilreport.org/ monthly-forecast/2017-05/bosnia_and_herzegovina_9.php?print=true. Pristupljeno 20. 7. 2018. 
Seham, Areff. 2015. Anything but War is good enough - Conflict mapping Sarajevo, Bosnia and Herzegovina. Generations for Peace Institute Research. The University of Oxford.

SNSD. 2013. Dejtonska struktura Bosne i Hercegovine i pravni položaj Republike Srpske. Dostupno na: http://www.snsd.org/images/dokumenti/dejtonska_struktura BiH_i_pravni_polozaj_rs.pdf. Posjećeno 12.4. 2019.

USAID. 2017. National Survey of Citizen's Perception in Bosnia and Herzegovina 2016. Dostupno na http://www.measureBiH.com/national-survey-of-citizens-perceptions. Pristupljeno 11. 5. 2018.

USAID. 2018. National Survey of Citizen's Perception in Bosnia and Herzegovina 2017. Dostupno na http://www.measureBiH.com/national-survey-of-citizens-perceptions. Pristupljeno 11. 5. 2018.

Vuković, Đorđe, Savanović, Aleksandar i Vranješ, Aleksandar. 2016. The Impossible State: National Identities in Bosnia and Herzegovina; u: Verdugo, R., Milne, A. (ur.): National Identity - Theory and Research. Information age publishing. Charlotte: 187-211.

Wellman, Christopher. 2005. A Theory of Secession. Cambridge University Press. Cambridge.

Wilkins, Burleigh. 2000. Secession. Peace Review, (12): 15-22.

Wybranowski, Dariusz. 2012. Will the Serbian Republic in Bosnia and Herzegovina be able to make it to independence? Certain political ambitions of President Milorad Dodik. Institute for Western Affairs, Bulletin (96).

XI izvještaj RS. 2014. Jedanaesti izvještaj Republike Srpske Savjetu bezbjednosti Ujedinjenih nacija. Dostupno na http://www.predsjednikrs.net/wp-content/ uploads/2019/09/11-Izvjestaj-Republike-Srpske-Savjetu-bezbjednosti-UN.pdf. Pristupljeno 28. 10. 2019.

XIV izvještaj RS. 2015. Četrnaesti izvještaj Republike Srpske Savjetu bezbjednosti Ujedinjenih nacija. Dostupno na http://www.predsjednikrs.net/wp-content/ uploads/2019/09/14-Izvjestaj-Republike-Srpske-SBUN.pdf. Pristupljeno 28. 10. 2019.

XV izvještaj RS. 2016.Petnaesti izvještaj RepublikeSrpske Savjetu bezbjednosti Ujedinjenih nacija. Dostupno na http://www.predsjednikrs.net/wp-content/uploads/2019/09/15.Izvjestaj-Republike-Srpske-SBUN.pdf. Pristupljeno 28. 10. 2019.

XVI izvještaj RS. 2016. Šesnaesti izvještaj Republike Srpske Savjetu bezbjednosti Ujedinjenih nacija. Dostupno na http://www.predsjednikrs.net/wp-content/ uploads/2019/09/16.-Izvjestaj-RS-SBUN1.pdf. Pristupljeno 28. 10. 2019.

XVII izvještaj RS. 2017. Sedamnaesti izvještaj Republike Srpske Savjetu bezbjednosti Ujedinjenih nacija. Dostupno na http://www.predsjednikrs.net/wp-content/ uploads/2019/09/17.-Izvjestaj-RS-SBUN.pdf. Pristupljeno 28. 10. 2019. 
XVIII izvještaj RS. 2017. Osamnaesti izvještaj Republike Srpske Savjetu bezbjednosti Ujedinjenih nacija. Dostupno na http://www.predsjednikrs.net/wp-content/ uploads/2019/09/18.-Izvjestaj-RS-SBUN-sa-popratnim-pismom.pdf. Pristupljeno 28. 10. 2019.

XIX izvještaj RS. 2018. Devetnaesti izvještaj Republike Srpske Savjetu bezbjednosti Ujedinjenih nacija. Dostupno na http://www.predsjednikrs.net/wp-content/ uploads/2018/05/19-Izvjestaj-RS-SBUN.pdf. Pristupljeno 28. 10. 2019.

Aleksandar Savanović, Aleksandar Vranješ, Nevenko Vranješ, Željko Budimir

THE ORIGINS, GENESIS AND NATURE OF THE SECESSIONIST RHETORIC IN THE REPUBLIC OF SRPSKA

\begin{abstract}
Summary
Bosnia and Herzegovina $(\mathrm{BiH})$ is a complex state union composed of two entities and three constituent peoples. This fact is a consequence of the 1992-95 civil war, which changed the ethnic structure of $\mathrm{BiH}$. From the institutional perspective, the two entities were given in Dayton a high level of political autonomy. The so-called "entity veto" was created in Dayton, and it is implemented by many key political bodies - from the House of Peoples and the House of Representatives of the Parliamentary Assembly of $\mathrm{BiH}$ to the Presidency of Bosnia and Herzegovina. Beside that, it is argued that $\mathrm{BiH}$ lacks the "internal recognition" and many of the political actors advocate radical constitutional changes which would disrupt or even completely change the "Dayton" architecture of $\mathrm{BiH}$. Because of that it is not surprising that secessionist rhetoric exists in BiH's political sphere. The secessionist rhetoric in the Republic of Srpska (RS) will be analysed in this paper and possible secessionist strategy will be described. The aim of this paper is to determine whether secessionist arguments, rhetoric and possibly politics represent an integral strategy and coherent political platform, or whether they are just generated for daily political purposes. Authors will also try to determine whether this secessionist rhetoric is "institutionalised", i.e. whether it is present in official documents of RS institutions and/or major political parties, or just in the activities of social movements and/or individual political subjects.
\end{abstract}

Keywords: Secession, Republic of Srpska, Bosnia and Herzegovina, Constitution of Bosnia and Herzegovina, Dayton Peace Agreement

\begin{abstract}
Aleksandar Savanović je vanredni profesor na katedri za politikologiju Fakulteta političkih nauka Univerziteta u Banjoj Luci.
\end{abstract}

Aleksandar Vranješ je docent na katedri za politikologiju Fakulteta političkih nauka Univerziteta u Banjoj Luci. 
Nevenko Vranješ je docent na katedri za politikologiju Fakulteta političkih nauka Univerziteta u Banjoj Luci.

Željko Budimir je viši asistent na katedri za politikologiju Fakulteta političkih nauka Univerziteta u Banjoj Luci.

Kontakti:

Aleksandar Savanović, Fakultet političkih nauka Univerziteta u Banjoj Luci, Vojvode Petra Bojovića 1A, 78000 Banja Luka, Bosna i Hercegovina. E-mail: aleksandar.savanovic@fpn.unibl.org

Aleksandar Vranješ, Fakultet političkih nauka Univerziteta u Banjoj Luci, Vojvode Petra Bojovića 1A, 78000 Banja Luka, Bosna i Hercegovina. E-mail: aleksandar. vranjes@fpn.unibl.org

Nevenko Vranješ, Fakultet političkih nauka Univerziteta u Banjoj Luci, Vojvode Petra Bojovića 1A, 78000 Banja Luka, Bosna i Hercegovina. E-mail: nevenko.vranjes@fpn.unibl.org

Željko Budimir, Fakultet političkih nauka Univerziteta u Banjoj Luci, Vojvode Petra Bojovića 1A, 78000 Banja Luka, Bosna i Hercegovina. E-mail: zeljko.budimir@fpn.unibl.org 